\title{
RADON AND RADON-DAUGHTER CONCENTRATIONS \\ IN AIR IN THE VICINITY OF \\ THE ANACONDA URANIUM MILL
}

by

Michael H. Momeni, J. B. Lindstrom,

C. E. Dungey, and Walter E. Kisieleski
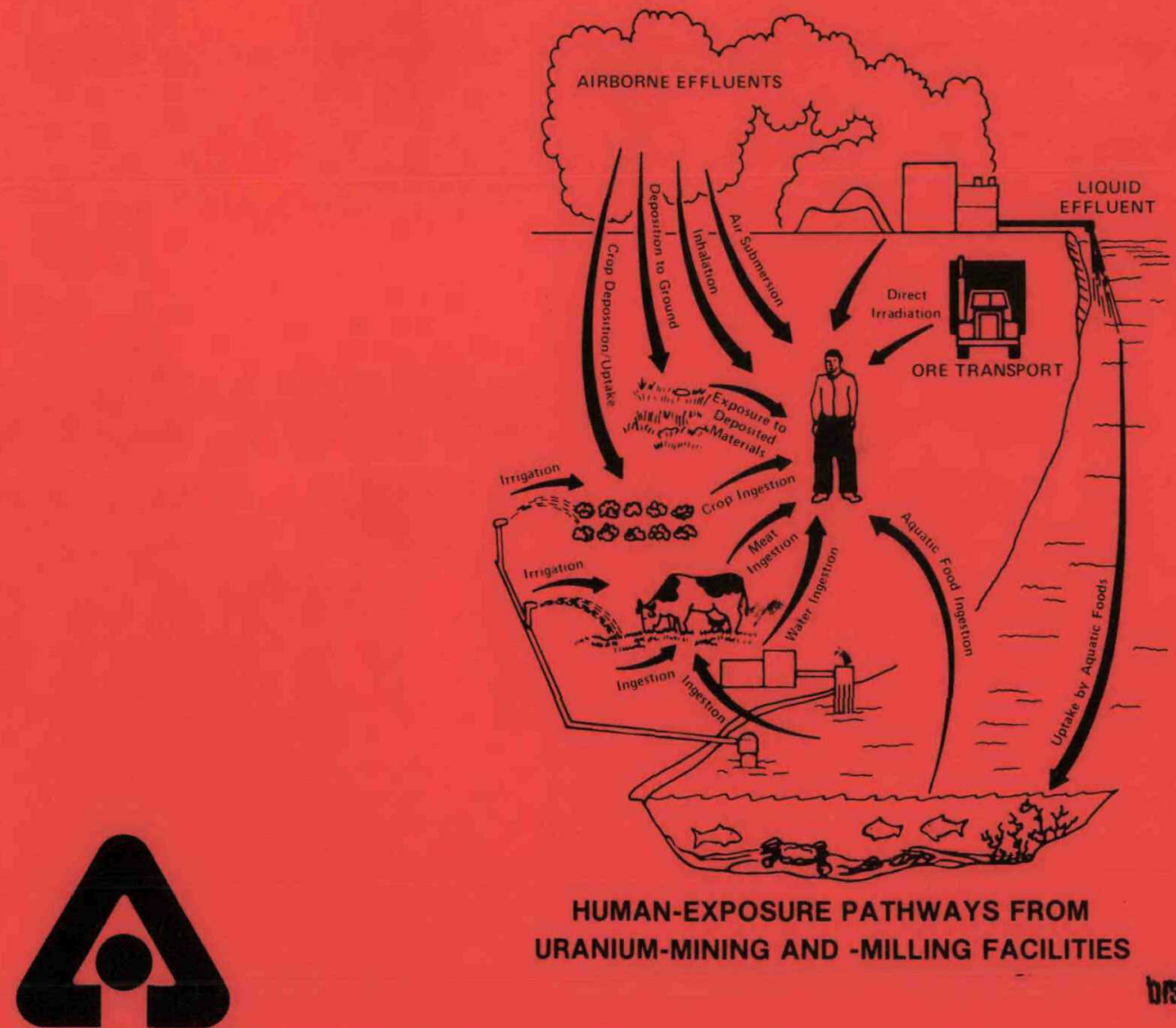

HUMAN-EXPOSURE PATHWAYS FROM URANIUM-MINING AND -MILLING FACILITIES

DRThBBUTION OF THIS DOCUMENT IS UHELMITES

UOIC-AUA-USDOE

ARGONNE NATIONAL LABORATORY, ARGONNE, ILLINOIS

Prepared for the U. S. NUCLEAR REGULATORY COMMISSION under Interagency Agreement DOE 40-550-75 
The facilities of Argonne National Laboratory are owned by the United States Government. Under the terms of a contract (W-31-109-Eng-38) among the U.S. Department of Energy, Argonne Universities Association and The University of Chicago, the University employs the staff and operates the Laboratory in accordance with policies and programs formulated, approved and reviewed by the Association.

\section{MEMBERS OF ARGONNE UNIVERSITIES ASSOCIATION}

The University of Arizona

Carnegie-Mellon University

Case Western Reserve University

The University of Chicago

University of Cincinnati

Illinois Institute of Technology

University of Illinois

Indiana University

The University of Iowa

Iowa State University
The University of Kansas

Kansas State University

Loyola University of Chicago

Marquette University

The University of Michigan

Michigan State University

University of Minnesota

University of Missouri

Northwe stern University

University of Notre Dame
The Ohio State University

Ohio University

The Pennsylvania State University

Purdue University

Saint Louis University

Southern Illinois University

The University of Texas at Austin

Washington Univer sity

Wayne State University

The University of Wisconsin-Madison

\section{NOTICE}

This report was prepared as an account of work sponsored by an agency of the United States Government. Neither the United States Government nor any agency thereof, nor any of their contractors, subcontractors, or any of their employees, makes any warranty, expressed or implied, or assumes any legal liability or responsibility for any third party's use, or the results of such use, of any information, apparatus, product or process disclosed in this report, or represents that its use by such third party would not infringe privately-owned rights.

Available from 


\section{DISCLAIMER}

This report was prepared as an account of work sponsored by an agency of the United States Government. Neither the United States Government nor any agency Thereof, nor any of their employees, makes any warranty, express or implied, or assumes any legal liability or responsibility for the accuracy, completeness, or usefulness of any information, apparatus, product, or process disclosed, or represents that its use would not infringe privately owned rights. Reference herein to any specific commercial product, process, or service by trade name, trademark, manufacturer, or otherwise does not necessarily constitute or imply its endorsement, recommendation, or favoring by the United States Government or any agency thereof. The views and opinions of authors expressed herein do not necessarily state or reflect those of the United States Government or any agency thereof. 


\section{DISCLAIMER}

Portions of this document may be illegible in electronic image products. Images are produced from the best available original document. 
NUREG/CR-1320

ANL/ES-89

Distribution

Code: RU

ARGONNE NATIONAL LABORATORY

9700 South Cass Avenue

Argonne, Illinois 60439

\section{MEASURED CONCENTRATIONS OF RADIOACTIVE PARTICLES IN AIR IN THE VICINITY OF THE ANACONDA URANIUM MILL}

by

Michael H. Momeni and Walter E, Kisieleski

Project Manager: Walter E. Kisieleski

Division of Environmental Impact Studies

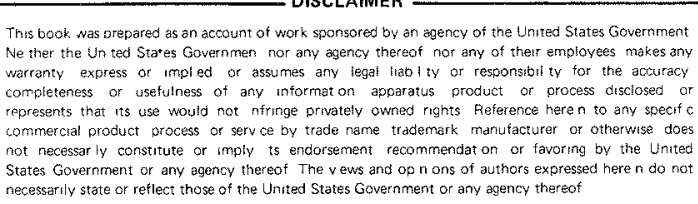

February 1980

Prepared for

Office of Nuclear Regulatory Research

U.S. Nuclear Regulatory Commission Washington, DC 20555

Under Interagency Agreement DOE 40-550-75

NRC FIN No. A2046 


\section{FOREWORD}

The Argonne National Laboratory, under contract with the U.S. Nuclear Regulatory Commission (NRC), Division of Safeguards, Fuel Cycle and Environmental Research, has conducted extensive long-term field studies at operating uranium mills to provide input for the Generic Environmental Impact Statement on Uranium Milling being prepared by the NRC.

The overall field study program was intended to:

(1) Provide measurements that could be used to characterize and to estimate the rates of release of airborne radioactive effluents (source terms) for uranium milling activities. This would include release rates of radioactive particulates (specific nuclides) and radon-222 from (a) mill stacks and vents, (b) ore piles, and (c) tailings piles.

(2) Provide data that could be used to verify predicted offsite environmental concentrations of radionuclides based on source terms and dispersion calculations.

(3) Provide data that could be used to evaluate the potential radiological significance of food ingestion pathways for airborne effluents released from uranium mills, focusing primarily on ingestion exposures associated with grazing animals and locally raised food crops or garden produce.

(4) Serve as a means to test, demonstrate, and evaluate environmental monitoring methods and techniques in order to provide information that could be used in the development of guidance for monitoring programs.

As part of this broad field study program, measurements were made at an operating uranium milling facility to characterize and establish airborne concentration levels of $\mathrm{U}-238, \mathrm{Th}-230, \mathrm{Ra}-226$, and $\mathrm{Pb}-210$. The data and results are presented in this report. Site-specific climatological and meteorological factors are assessed. Measured airborne concentration of radioactive particles are compared to natural background levels and to maximum permissible concentrations.

This is one in a series of reports leading to comparison of experimentally determined gaseous and airborne particulate concentrations with theoretically predicted concentrations such as by the UDAD Code (Momeni et al. 1979a). Other published reports in this series are:

- "Uranium Dispersion and Dosimetry (UDAD) Code," NUREG/CR-0553, ANL/ES-72. Momeni et a1. (1979).

- "Radon and Radon-Daughter Concentrations in Air in the Vicinity of the Anaconda Uranium Mil1," NUREG/CR-1133, ANL/ES-81, Momeni et a1. (1979). 
- "Radioisotopic Composition of Yellowcake: An Estimation of Stack Release Rates," NUREG/CR-1216, ANL/ES-84. Momeni et a1. (1979).

Other reports on size distribution of airborne particulates, characterization and size distribution of ore and tailings solids, ground migration of ground-deposited radionuclides and ground contamination will be issued in the future.

The authors express their appreciation to Drs. L. Roberts (Argonne National Laboratory), L. Schwendiman (Battelle-Pacific Northwest Laboratory), P. Magno, W. Fort, and D. Hendricks (U.S. Environmental Protection Agency) for their critical reviews of this report before publication. The authors are indebted to the management and staff of the Kerr-McGee Nuclear Corporation, the Anaconda Company (Bluewater NM Operation), Exxon (Highland Uranium Operation), and Union Carbide (Uravan Uranium Operation) for their cooperation and assistance during this research.

The overall study was conducted by the Division of Environmental Impact Studies at Argonne National Laboratory. This activity was monitored by Harry Landon, Paul Magno (now with EPA-Washington), Hubert Miller, and presently Ms. Laura Santos (NRC). 


\section{CONTENTS}

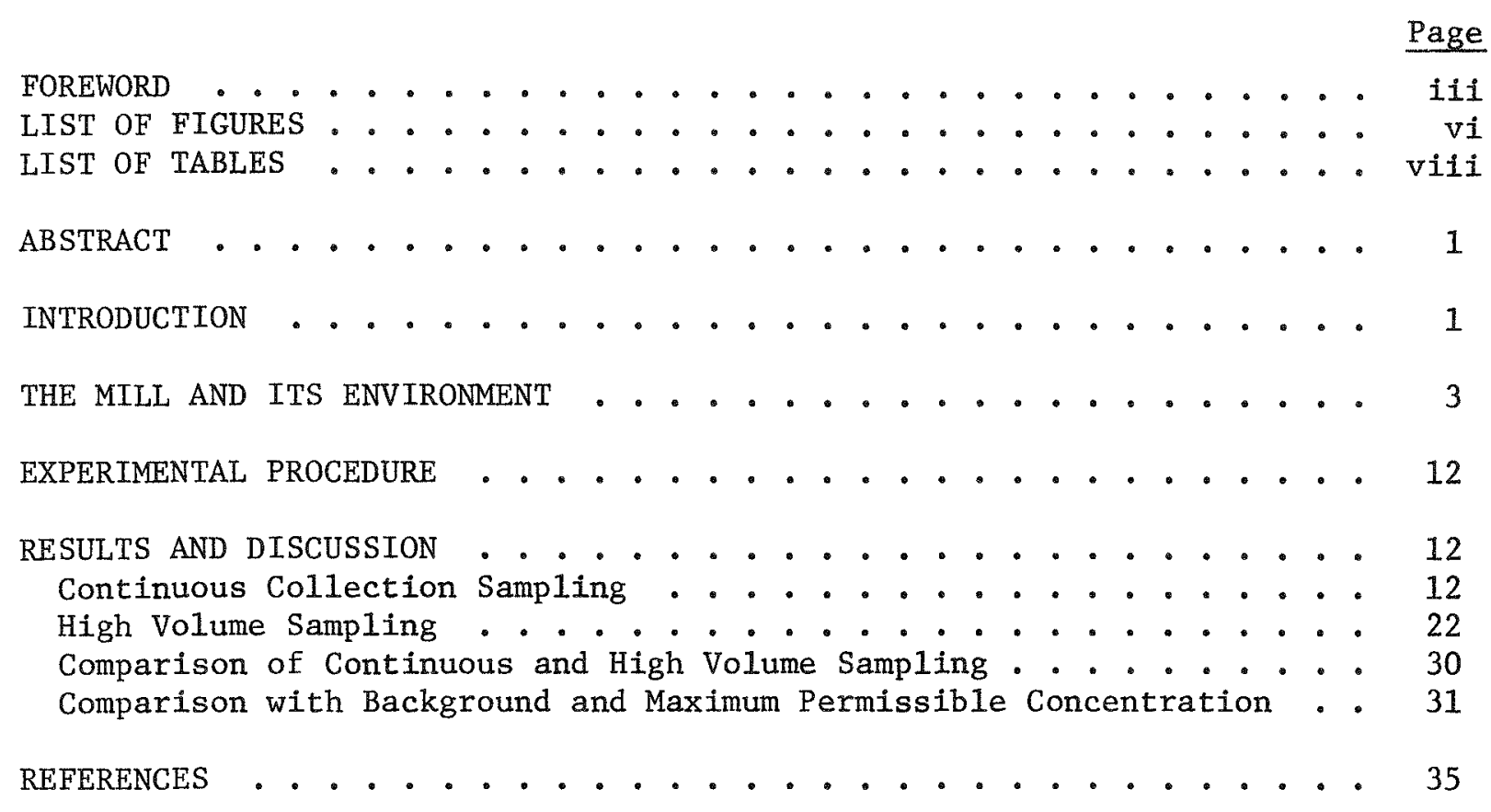




\section{LIST OF FIGURES}

Figure

$\underline{\text { Page }}$

1 Location of the Anaconda Uranium Mill at Bluewater, New Mexico, in the Grants Mineral Belt . . . . . . . . . . 4

2 Schematic Map of Anaconda Mill Site Showing Locations of the Mill, Ore Pad, Tailings Retention Area, and Monitoring Stations . . . . . . . . . . . . . . 5

3 The Anaconda Uranium Mill and Tailings Pond before 1979 . . . . 6

4 Aerial View of the Anaconda Uranium Mill . . . . . . . . . 7

5 Anaconda Tailings Retention Area; View from the Western Embankment ..................... 8

6 Anaconda Tailings Retention Area; View Showing the Southern Embankment and the Solution Pond in the Foreground . . . . . . . 8

7 Wind Rose . . . . . . . . . . . . . . . . . . 9

81977 Wind Speed Data, Anaconda Mi11 . . . . . . . . . 10

91978 Wind Speed Data, Anaconda Mi11 . . . . . . . . . 10

10 Photo of Representative Sampling Station . . . . . . . . . 13

11 Airborne Concentrations of U-238 as Measured by Continuous Collection Method . . . . . . . . . . . . . .

12 Airborne Concentrations of Th-230 as Measured by Continuous Collection Method . . . . . . . . . . . . . . . . . .

13 Airborne Concentrations of $\mathrm{Ra}-226$ as Measured by Continuous Collection Method ...................

14 Airborne Concentrations of $\mathrm{Pb}-210$ as Measured by Continuous Collection Method . . . . . . . . . . . . . . . . . .

15 Airborne Concentrations of U-238 as Measured by High Volume Collection Method . . . . . . . . . . . . . .

16 Airborne Concentrations of Th-230 as Measured by High Volume Collection Method . . . . . . . . . . . . . . . 


\section{LIST OF FIGURES (Continued)}

Figure

Page

17 Airborne Concentrations of Ra-226 as Measured by High Volume Collection Method . . . . . . . . . . . . . .

18 Airborne Concentrations of $\mathrm{Pb}-210$ as Measured by High Volume Collection Method . . . . . . . . . . . . . . . 28 


\section{LIST OF TABLES}

Table

1 Daily wind Speed Distribution . . . . . . . . . . . 11

2 Radionuclide Concentrations in Air Measured at Station 102 Using Continuous Collection Method . . . . . . . . . . . .

3 Radionuclide Concentrations in Air Measured at Station 103 Using Continuous Collection Method . . . . . . . . . . 15

4 Radionuclide Concentrations in Air Measured at Station 104 Using Continuous Collection Method . . . . . . . . . . . 16

5 Concentrations of Airborne Radionuclides Normalized to Uranium Concentration as Measured by Continuous Collection Method

6 Radionuclide Concentrations in Air Measured at Station 100 Using High Volume Sampler . . . . . . . . . . . . .

7 Radionuclide Concentrations in Air Measured at Station 101 Using High Volume Sampler . . . . . . . . . . . . .

8 Radionuclide Concentrations in Air Measured at Station 104 Using High Volume Sampler . . . . . . . . . . . . 24

9 Radionuclide Concentrations in Air Measured at Station 105 Using High Volume Sampler . . . . . . . . . . . . 24

10 Average Airborne Concentrations of U-Nat, Th-230, Ra-226, and $\mathrm{Pb}-210$ as Collected by Anaconda Company Using High Volume Air Sampling System for the Last Six Months of 1978 . . •.

11 Average Airborne Concentrations of U-Nat, Th-230, Ra-226, and $\mathrm{Pb}-210$ as Collected by Anaconda Company Using High

Volume Air Sampling System for the First Six Months of 1979 . . . 30

12 Comparison of Airborne Concentrations of Radionuclides Measured Using Continuous Collection and High Volume Air Samp1ing Procedures ................... 31

13 Comparison of the Average Particulate Concentrations Measured with the Maximum Permissible Concentration for Soluble and Insoluble Radionuclides . . . . . . . . . . 


\title{
MEASURED CONCENTRATIONS OF RADIOACTIVE PARTICLES IN AIR IN THE VICINITY OF THE ANACONDA URANIUM MILL
}

\author{
by
}

Michael H. Momeni and Walter E. Kisieleski

\begin{abstract}
Concentrations of radioactive particles (U-238, Th-230, Ra-226, and $\mathrm{Pb}-2(0)$ in air were measured in the vicinity of the Anaconda Uranium Mill, Bluewater, New Mexico. Airborne particles were collected at three stations for about two-thirds of a year using a continuous collection method at a sampling rate of $10 \mathrm{~L} / \mathrm{min}$, and also were measured in monthly composites collected periodically at four stations using "high volume" air samplers at a sampling rate of $1400 \mathrm{~L} / \mathrm{min}$. The ratios of concentrations of each radionuclide to the concentrations of U-238 indicate that the concentrations of the radionuclides are influenced principally by the proximity of the major sources of emission and the direction of the wind. In all cases, the concentration of $\mathrm{Pb}-210$ exceeded that of $\mathrm{U}-238$. The ratio of $\mathrm{Pb}-210 / \mathrm{U}-238$ was 12.3 and 13.3 for stations dominated by the emissions from the tailings and ore pads, but was only 1.6 for the station dominated by the yellowcake stack emission. The ratio of the radionuclide concentrations measured by the two methods of sample collection was between 0.8 and 1.2 for uranium, radium, and lead at station 104 , but was 0.28 to 1.7 for thorium, radium, and lead at stations 101 and 102. The average concentrations calculated from the measurements made in this study suggest that releases from the Anaconda mill were well within the existing limits of the maximum permissible concentrations for inhalation exposure of the general public (10 CFR Part 20, Appendix B).
\end{abstract}

\section{INTRODUCTION}

All mining and milling operations are souxces of airborne particles through direct discharge into the atmosphere and through fugitive dust loading attendant to alteration of the ground surface. Uranium mining and milling, because of the high radioactivity of the ore, present a potential radiationinduced health hazard. Release of radioactive airborne particles (principally the uranium-238 series) from these sources causes increased human exposure to radioactivity through the pathways of inhalation, ingestion of food grown on contaminated ground or in contact with contaminated water, and external exposure.

Atmospheric aerosols, relatively stable, minute, suspended particles in air, are natural components of the air we breath. The concentration of aerosols in the urban environment might average about $100 \mu \mathrm{g} / \mathrm{m}^{3}$ (NCRP \#45 1975), but 
varies widely. In the unpolluted environment, average aerosol concentrations up to $50 \mu \mathrm{g} / \mathrm{m}^{3}$ are encountered, but during short dust storms, concentrations several magnitudes higher are reached. The atmospheric residence time of suspended particles varies from several years for particles of $\simeq 0.5 \mu \mathrm{m}$ diameter in the stratosphere to a few minutes for larger particles near the surface of the ground.

In contrast to the relatively brief residence time of most particulates (i.e. radioactive particles) in the atmosphere, ground contamination in the vicinity of milling operations from deposition of airborne particulates and movement of larger grains of ore and tailings will persist for a long period, especially in the arid mining regions of the West. In addition, transport of ground surface contaminants by runoff will result in accumulation of radioactive material in drainageways and reservoirs.

Background concentrations of airborne particulates mirror the distribution of these radionuclides in soil, except for $\mathrm{Pb}-210$ and $\mathrm{Po}-210$, which include contributions from decay of airborne Rn-222. The background concentration of radionuclides in general is dependent on regional topography and wind speed. Although they may be present only in minute, gravimetric quantities, radionuclides such as thorium (Th-230) in the atmosphere may pose a more significant potential health hazard than the relatively large quantities of resuspended natural soil and sand.

Predictions of the radiological impacts from particulates released during uranium milling operations (U-238, $\mathrm{U}-234, \mathrm{Th}-230, \mathrm{Ra}-226$, and $\mathrm{Pb}-210$ ) are based on:

1. Estimates of the average aerosol release rate from each source of emission.

2. Spatial and temporal distributions of the aerosols within the atmosphere.

3. Estimates of dose and dose rate to the population in the vicinity of the mill.

4. Estimates of health effects based on dose rate, dose, and age.

Major sources of particulate emissions at uranium mills are ore pads (the storage piles of ore at the mill), ore-crushing and-grinding operations, stacks venting gases from yellowcake-drying and -packaging operations, and fugitive dust from dried surfaces of tailings piles.

The rates of release of particulates from these sources are dependent on the procedures employed to control fugitive dust (Momeni et al. 1979c) and on site-specific climatological and meteorological factors.

The purpose of this study was to obtain field data on concentrations of the radionuclides in the air in the vicinity of an operating uranium mill and on site-specific meteorology for comparison with theoretical predictions based on mathematical models incorporated into computer codes such as the UDAD Code (Momeni et al. 1979a) for estimation of radiological impacts based on dose and 
dose rates from uranium milling operations (NRC 1979). To achieve this objective, the following parameters were measured at the Anaconda Uranium Mill near Bluewater, New Mexico (Fig. 1):

- Meteorological Parameters

Wind speed a d direction were measured continuously for about one year.

- Aerosol Concentrations

1. Airborne particulates were collected at three sampling stations at the Anaconda mill (Fig. 2) for about two-thirds of a year using a "continuous collection" technique at an air-sampling rate of $10 \mathrm{~L} / \mathrm{min}$. The concentrations of the radionuc1ides $\mathrm{U}-238$, $\mathrm{Th}-230, \mathrm{Ra}-226$, and $\mathrm{Pb}-210$ were measured in monthly composite samples.

2. Airborne concentrations of the same radionuclides also were measured in monthly composites collected periodically at four stations using a high volume sampling technique at an air-sampling rate of $1400 \mathrm{~L} / \mathrm{min}$.

\section{THE MILL AND ITS ENVIRONMENT}

The field study for this report was conducted at the Anaconda Uranium Mil1 (Figs. 1 through 3), Bluewater, New Mexico, between 1977 and 1978. Between 1955 and 1978, an acid leaching process was used at the Anaconda mill to extract uranium; the daily throughput was about 2500 tonnes of ore containing about $0.25 \%$ uranium $\left(\mathrm{U}_{3} \mathrm{O}_{8}\right)$. At present, the mill processes 5400 tonnes of ore per day with an ore quality of less than $0.2 \%$ uranium.

The tailings from the uranium extraction currently are pumped to a retention pond that covers about $1.1 \mathrm{~km}^{2}$ and is about $8 \mathrm{~m}$ above the basaltic rock formation. The tailings retention area (Figs. 4, 5, and 6) is constructed in a natural basin to the north of the plant area. The basin was formed by the higher mesas to the east and north and higher lava flow escarpment to the south and west. Two small seasonal lakes were formed from the adjacent watersheds by runoff. The dry beach tailing solids area has been reduced by keeping surfaces moist since reconstruction of the tailings dam and adoption of a protocol for tailings management similar to that described by Momeni et al. (1979c).

The estimated entire beach surface area (moist and dry) was $0.64 \mathrm{~km}^{2}$ before 1979 and $0.96 \mathrm{~km}^{2}$ thereafter. During dry seasons, surface moisture has varied from very dry (moisture content less than $0.5 \%$ ) to wet (saturated) at the edge of the solution. Calculation of average moisture is not feasible at this time, but a study in progress using aerial photography and ground measurements may provide a moisture isopleth in the future. The median tailings grain diameter was $250 \mu \mathrm{m}$ and $350 \mu \mathrm{m}$, respectively, as measured in composite samples obtained from surface areas at southern and eastern sections of the tallings retention area. Detailed characterization of tailings solids will be reported in the future. 


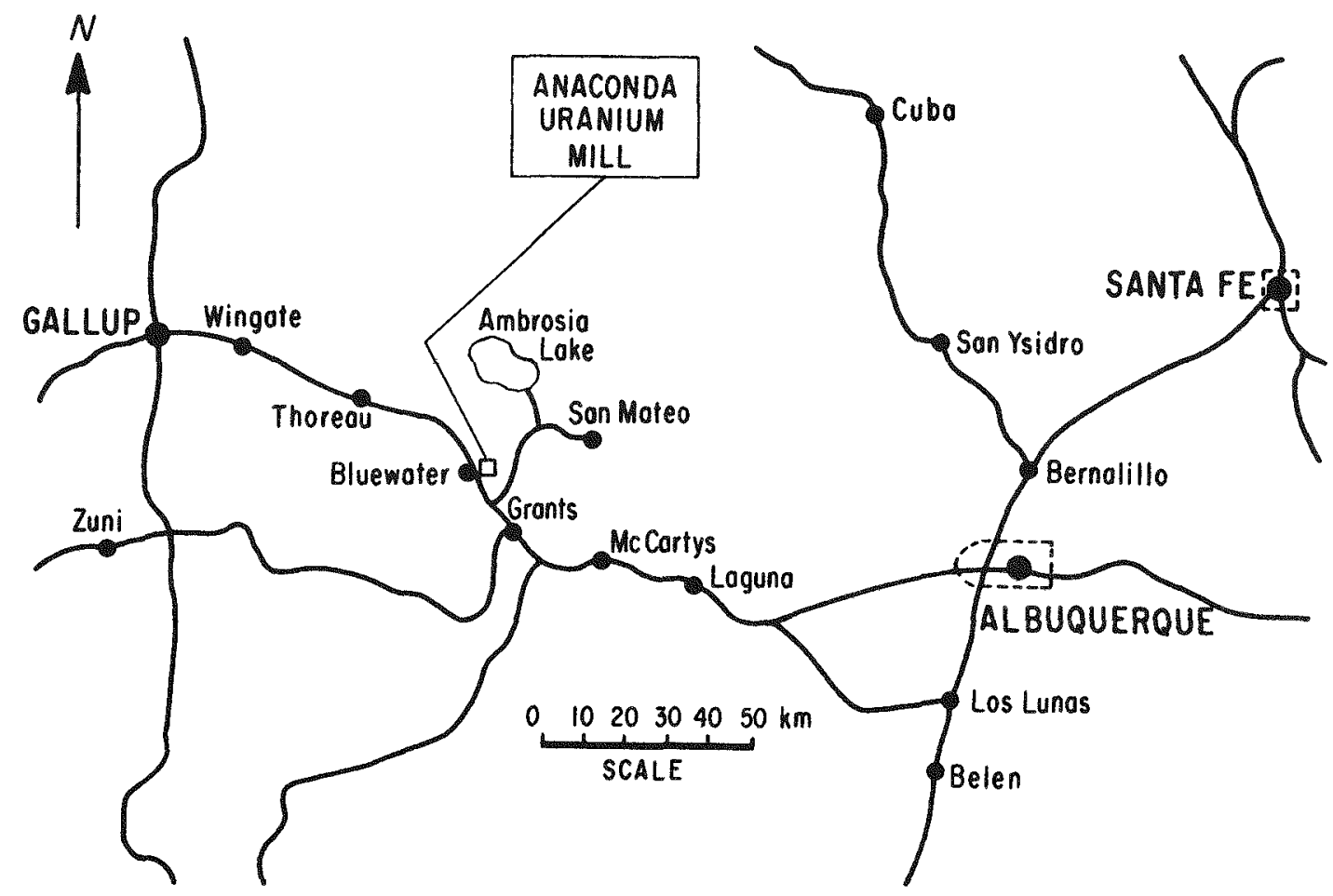

Figure 1. Location of the Anaconda Uranium Mill at Bluewater, New Mexico, in the Grants Mineral Belt.

Before reconstruction of the dikes, tailings overflowed and were collected in catch basins. These deposits are about $125 \mathrm{~cm}$ deep. Between 1953 and 1956 Anaconda also operated a carbonate leach process. The tailings from this process were separated from those of the acid leach process, and in late 1977, these inactive carbonate leach tailings were covered with an average of $85 \mathrm{~cm}$ of siltclay. It is estimated that currently about 32 million tonnes of tailings are stored at the Anaconda mill. These tailings contain about 20,000 $\mathrm{Ci}$ each of $\mathrm{Th}-230, \mathrm{Ra}-226, \mathrm{~Pb}-210$, and $\mathrm{Po}-210$, and less than $2000 \mathrm{Ci}$ each of U238 and $\mathrm{U}-234$.

Details of the geology and meteorology of Bluewater have been reported previously (Momeni et a1. 1979b). Wind speed and direction measured during 1977-1978 are summarized in Table 1 and Figure 7. The average 24-hour wind speeds are shown as a function of time in Figures 8 and 9 for portions of 1977 and 1978. During the period covered, the wind conditions varied from nearly stagnate to speeds of about $20 \mathrm{mph}$. A seasonal variation also seems to be indicated, with the largest fluctuations in wind speed occurring during November-December 1977. The wind speed recorded during the period of midApril to May 1978 was near zero. The average wind speed was highest during the winter and lowest during autumn (Table 1 ). 


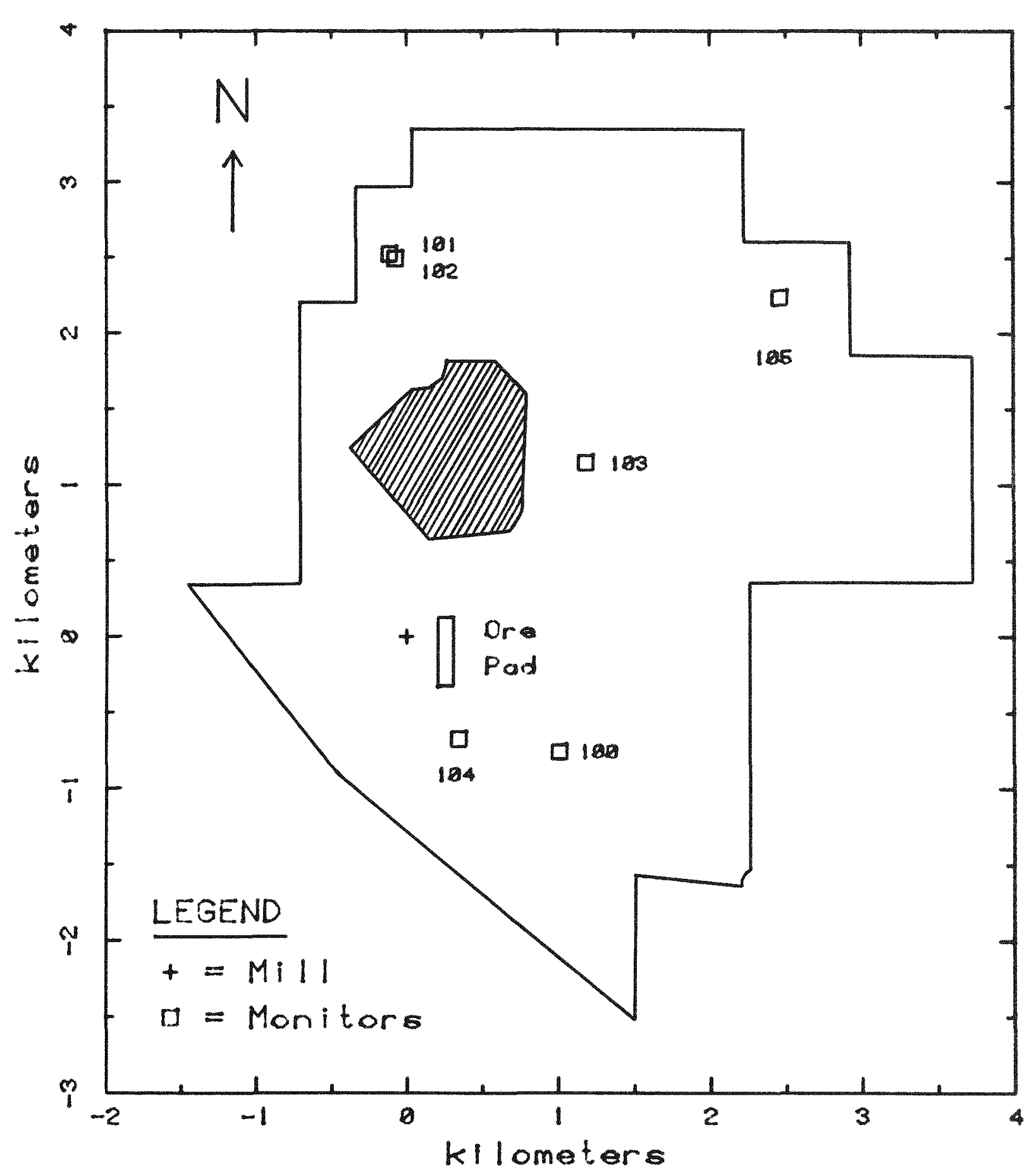

Figure 2. Schematic Map of Anaconda Mill Site Showing Locations of the Mill, Ore Pad, Tailings Retention Area, and Monitoring stations. (The cross-hatched section is the tailings retention area.) 


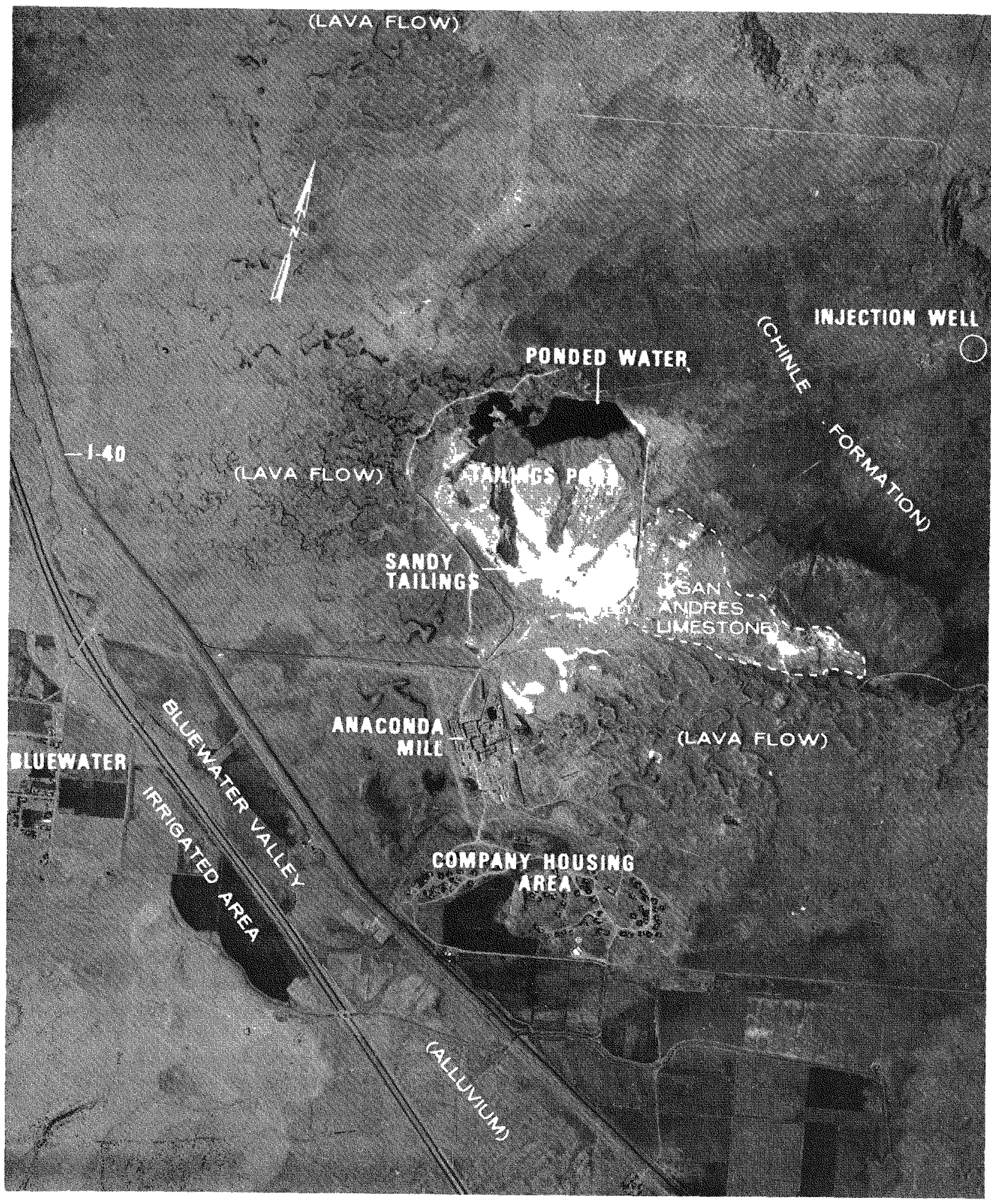

Figure 3. The Anaconda Uranium Mill and Tailings Pond before 1979. (From "Water Quality Impacts of Uranium Mining and Milling Activities in the Grants Mineral Belt, New Mexico,"U.S. EPA 906/9-75-002.) 


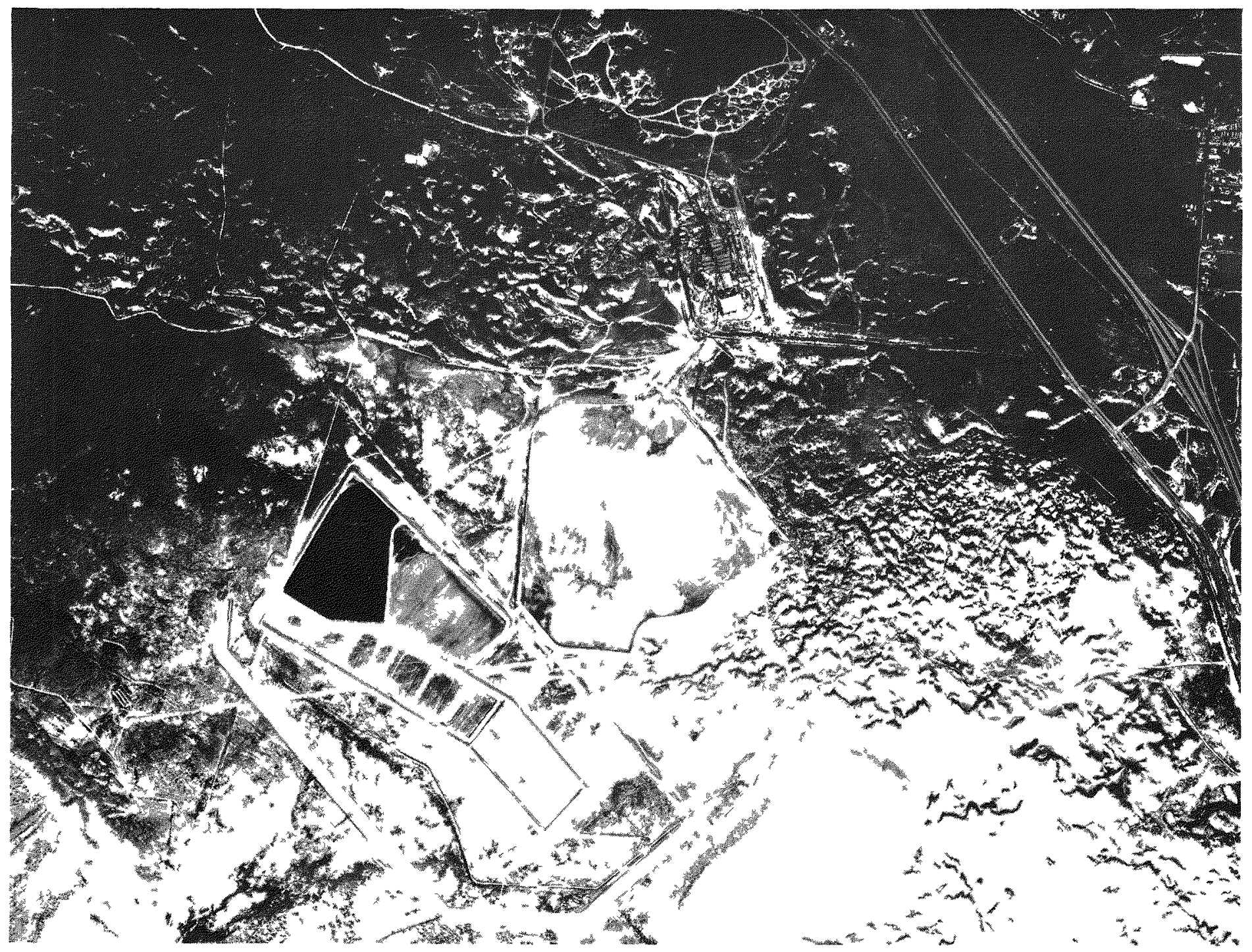

Figure 4. Aerial View of the Anaconda Uranium Mill (facilities to the upper righthand side of the tailings area were installed in 1978). 


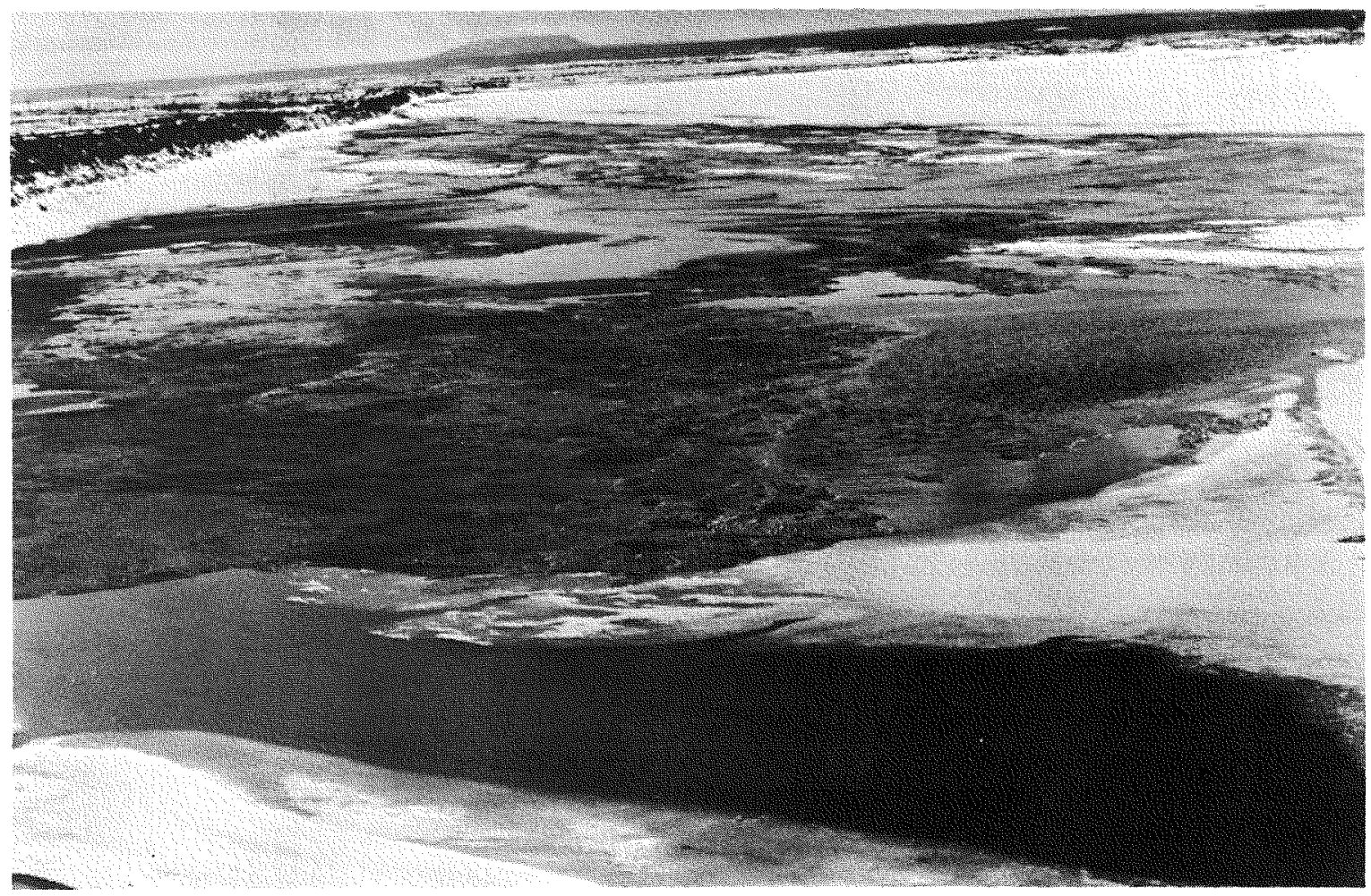

Figure 5. Anaconda Tailings Retention Area; View from the Western Embankment.

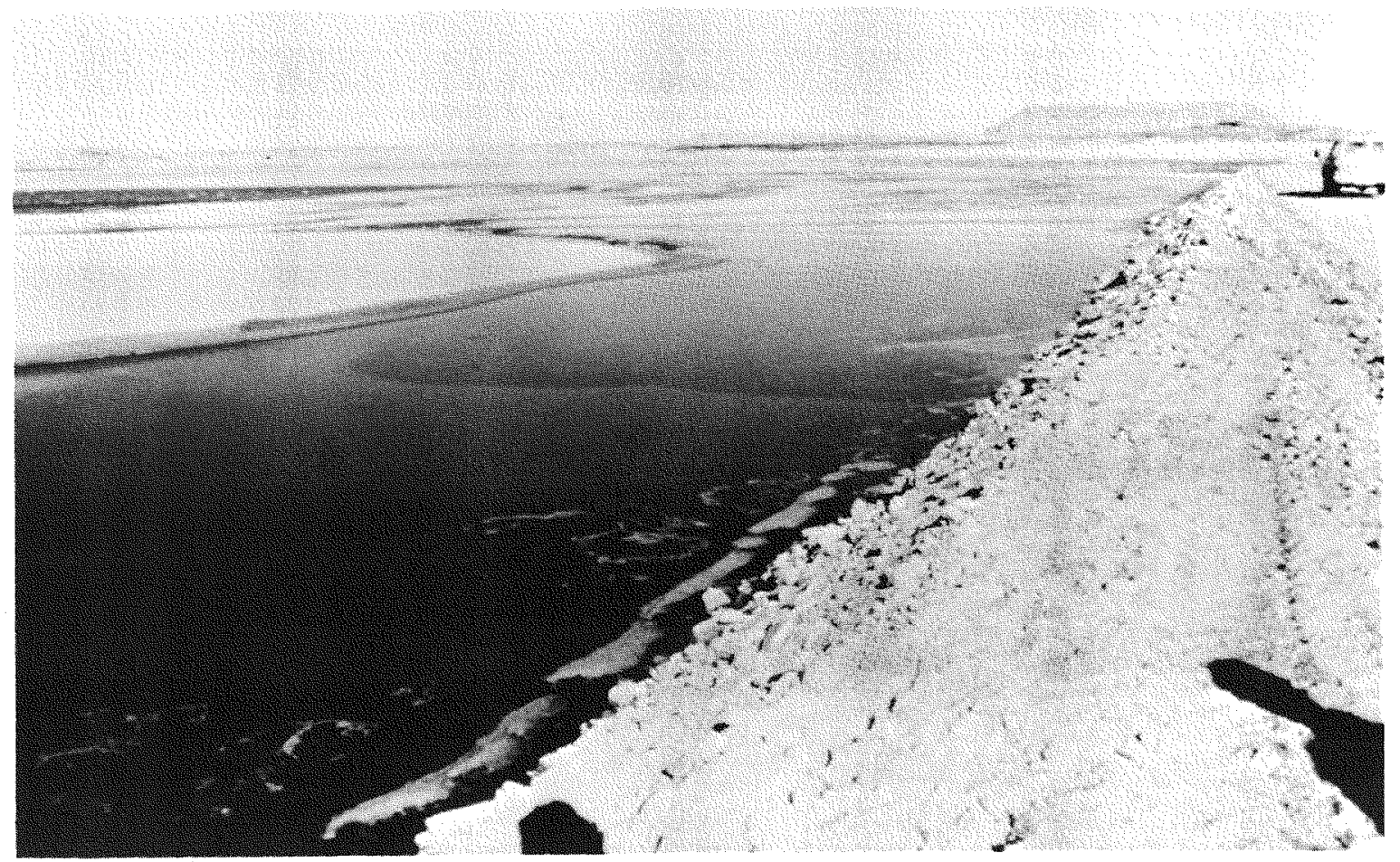

Figure 6. Anaconda Tailings Retention area in Foreground Showing the Southern Embankment and the Solution Pond. 


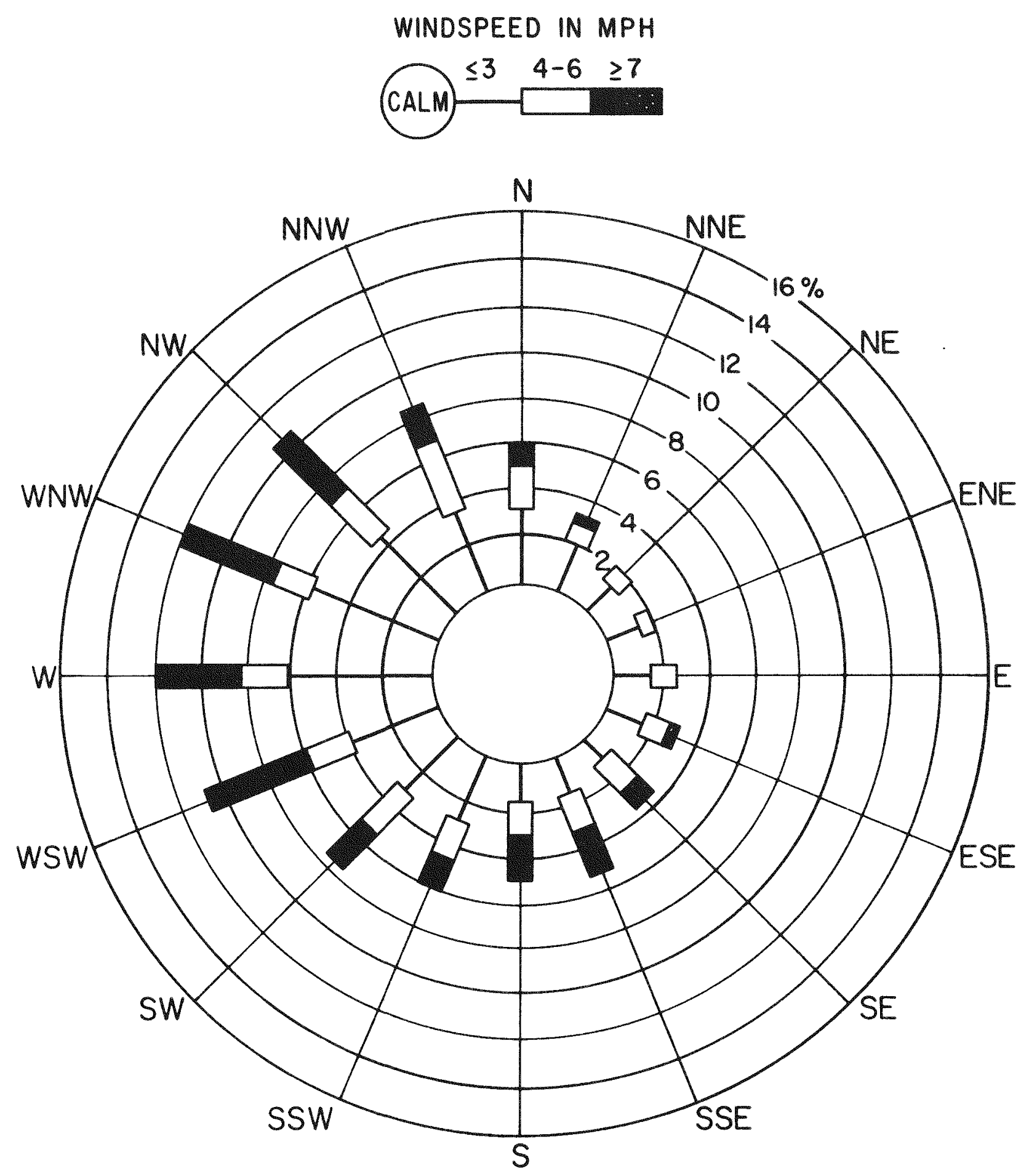

Figure 7. Wind Rose. (Data from Stations $102 \& 104,3-\mathrm{m}$ towers.) 


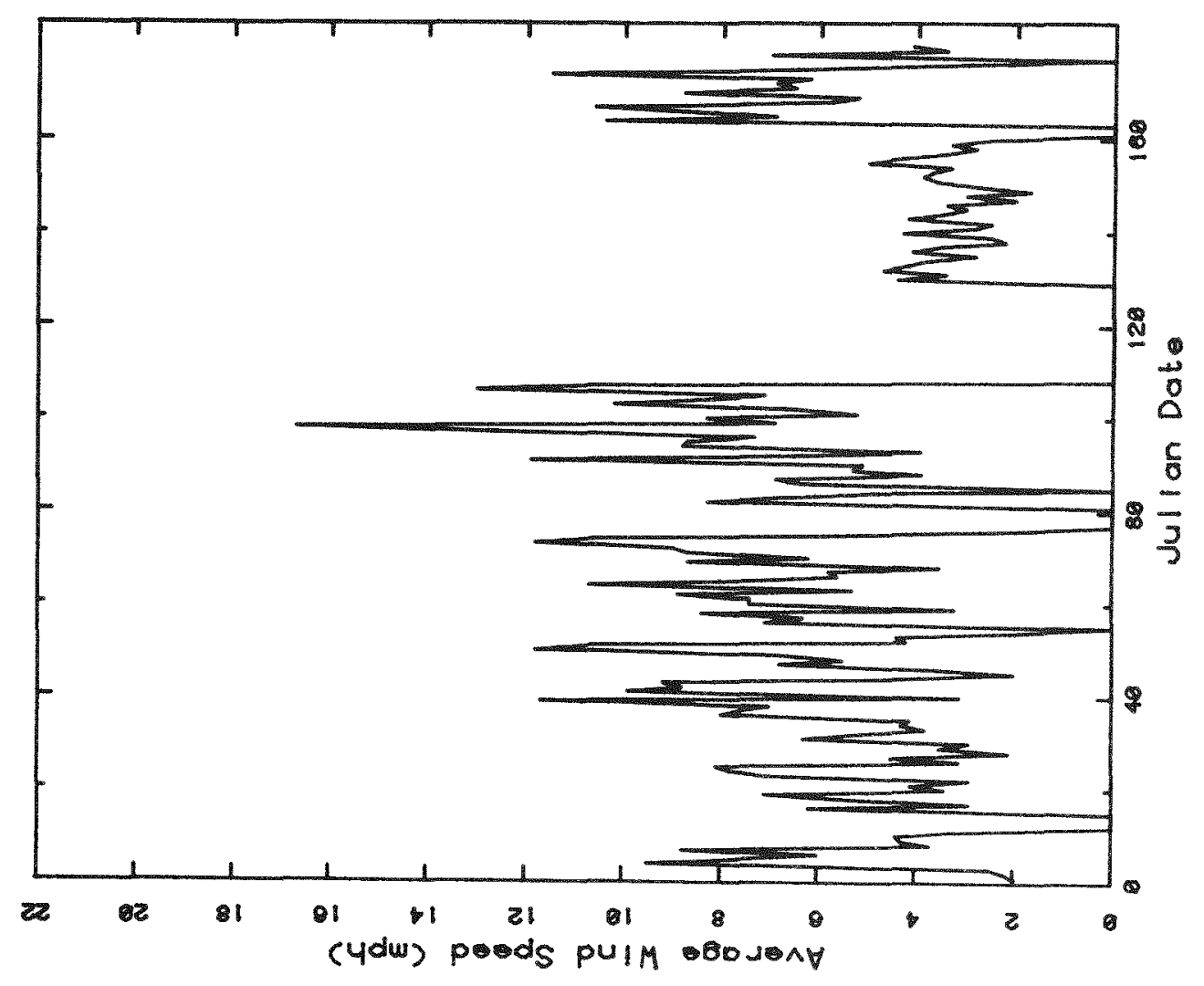

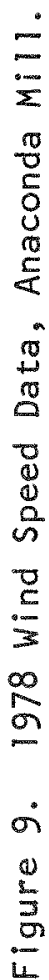

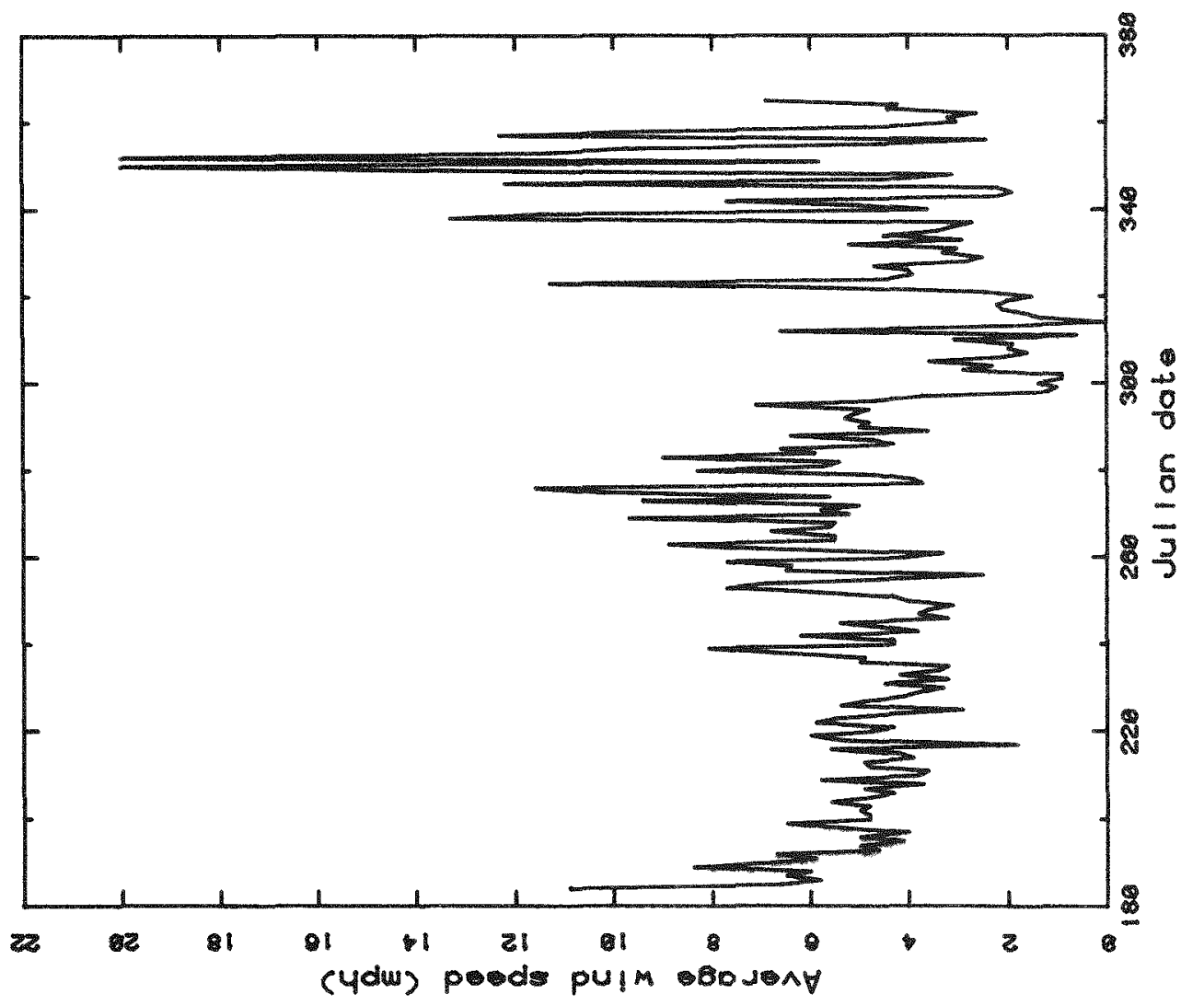

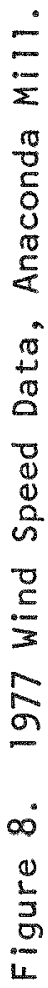


Table 1. Daily Wind Speed Distribution (mph)

\begin{tabular}{|c|c|c|c|c|c|}
\hline Hour & Summer & Autumn & Winter & Spring & Annual \\
\hline 0100 & 3.5 & 4.3 & 4.0 & 3.2 & 3.8 \\
\hline 0200 & 3.3 & 4.1 & 4.3 & 3.3 & 3.7 \\
\hline 0300 & 2.8 & 3.9 & 4.3 & 2.8 & 3.5 \\
\hline 0400 & 2.6 & 3.5 & 4.7 & 2.5 & 3.4 \\
\hline 0500 & 2.4 & 3.4 & 4.7 & 2.3 & 3.2 \\
\hline 0600 & 2.2 & 3.3 & 4.0 & 2.0 & 2.9 \\
\hline 0700 & 2.1 & 3.1 & 3.5 & 2.3 & 2.8 \\
\hline 0800 & 2.6 & 3.6 & 4.5 & 2.9 & 3.4 \\
\hline 0900 & 3.4 & 4.3 & 6.1 & 4.2 & 4.5 \\
\hline 1000 & 5.1 & 4.7 & 7.9 & 6.3 & 5.9 \\
\hline 1100 & 6.2 & 6.0 & 8.2 & 7.4 & 6.9 \\
\hline 1200 & 7.3 & 6.8 & 9.3 & 8.2 & 7.8 \\
\hline 1300 & 7.6 & 7.5 & 9.7 & 9.0 & 8.4 \\
\hline 1400 & 8.3 & 8.1 & 10.3 & 9.3 & 8.9 \\
\hline 1500 & 8.7 & 8.2 & 10.0 & 10.1 & 9.2 \\
\hline 1600 & 8.5 & 7.8 & 9.4 & 10.6 & 9.0 \\
\hline 1700 & 8.3 & 6.9 & 8.1 & 10.5 & 8.3 \\
\hline 1800 & 8.2 & 5.9 & 6.2 & 10.3 & 7.5 \\
\hline 1900 & 7.4 & 4.7 & 5.0 & 8.4 & 6.3 \\
\hline 2000 & 5.6 & 4.4 & 4.5 & 6.0 & 5.1 \\
\hline 2100 & 4.7 & 4.1 & 4.0 & 4.6 & 4.4 \\
\hline 2200 & 4.0 & 4.1 & 3.8 & 3.5 & 3.9 \\
\hline 2300 & 3.6 & 4.2 & 3.7 & 3.5 & 3.8 \\
\hline 2400 & 3.6 & 4.1 & 3.9 & 3.4 & 3.8 \\
\hline Average & 5.1 & 5.0 & 6.0 & 5.7 & 5.4 \\
\hline
\end{tabular}




\section{EXPERIMENTAL PROCEDURE}

Six air-sampling stations were operated in the vicinity of the Anaconda mil1 during portions of 1977 and 1978. The locations of the sampling stations are shown in Figure 2. Airborne particulate samples were collected using a continuous collection procedure at a flow rate of $10 \mathrm{~L} / \mathrm{min}$ at stations 102 , 103, and 104. Samples were collected using Andersen Hi Vol (high volume) air samplers operated at a flow rate of $1400 \mathrm{~L} / \mathrm{min}$ at stations 100, 101, 104, and 105. The experimental setup at a representative station is shown in Figure 10.

The system for continuous collection of airborne particulates on a 47-mm membrane filter has been described previously (Momeni et al. 1978). With this system, airborne particles were continuously collected from a height of $75 \mathrm{~cm}$ above the ground for periods of three to seven days, depending on the atmospheric dust concentration. The total collected filters were composited approximately monthly for measurement of average concentrations of uranium $(\mathrm{U}-238)$, thorium $(\mathrm{Th}-230)$, radium $(\mathrm{Ra}-222)$, and lead $(\mathrm{Pb}-210)$.

The Hi Vol air samplers were operated periodically for periods of 24 to 48 hours. Air was sampled at a height of about $3 \mathrm{~m}$ at stations 100, 101, and 104, and at about $7 \mathrm{~m}$ at station 105. The Hi Vol samplers were calibrated following the manufacturer's recommendations. The filters (cellulose Whatman 41) were composited to monthly samples for measurement of concentrations of radioactivity. Both before and after air-sample collection, selected filters were stored in a desiccator for about one day to minimize the effect of the hygroscopic properties of filters and aerosols on the small air-sample weights.

Radiochemical measurements of samples collected by both techniques were performed by Environmental Analysis Laboratory (LFE Corporation), Richmond, California.

\section{RESULTS AND DISCUSSION}

\section{Continuous Collection Sampling}

Airborne concentrations (and the standard errors of the analytical measurements) of $\mathrm{U}-238, \mathrm{Th}-230, \mathrm{Ra}-226$, and $\mathrm{Pb}-210$ sampled by the continuous collection method with a flow rate of $10 \pm 1 \mathrm{~L} / \mathrm{min}$ at stations 102,103 and 104 are given in Tables 2 through 4.

The average airborne concentration of uranium collected at station 102 (Table 2) was $2.2 \times 10^{-3} \mathrm{pCi} / \mathrm{m}^{3}$. The standard error of this average was $3.1 \times 10^{-4} \mathrm{pCi} \mathrm{U}-238 / \mathrm{m}^{3}$, about $14 \%$ of the mean. The range of concentration was $3.03 \times 10^{-4} \mathrm{pCi} / \mathrm{m}^{3}$ to $6.37 \times 10^{-3} \mathrm{pCi} / \mathrm{m}^{3}$. This range corresponds to a $21-$ fold change in airborne concentration of U-238. The average airborne concentrations $\left(\mathrm{pCi} / \mathrm{m}^{3}\right)$ of $\mathrm{U}-238$ at stations 103 (Table 3) and 104 (Table 4) were, respectively, $1.8 \times 10^{-3}$ (range $3.42 \times 10^{-4}$ to $2.9 \times 10^{-3}$ ) and $8.8 \times 10^{-3}$ (range $7.92 \times 10^{-4}$ to $3.23 \times 10^{-2}$ ). These ranges correspond to 8.5 -fold and 41-fold changes in U-238 concentrations. The changes in airborne U-238 concentrations with time are shown in Figure 11. Comparison of uranium concentrations among the three stations shows in general a lower concentration during July and November through December 1977, and a higher concentration 


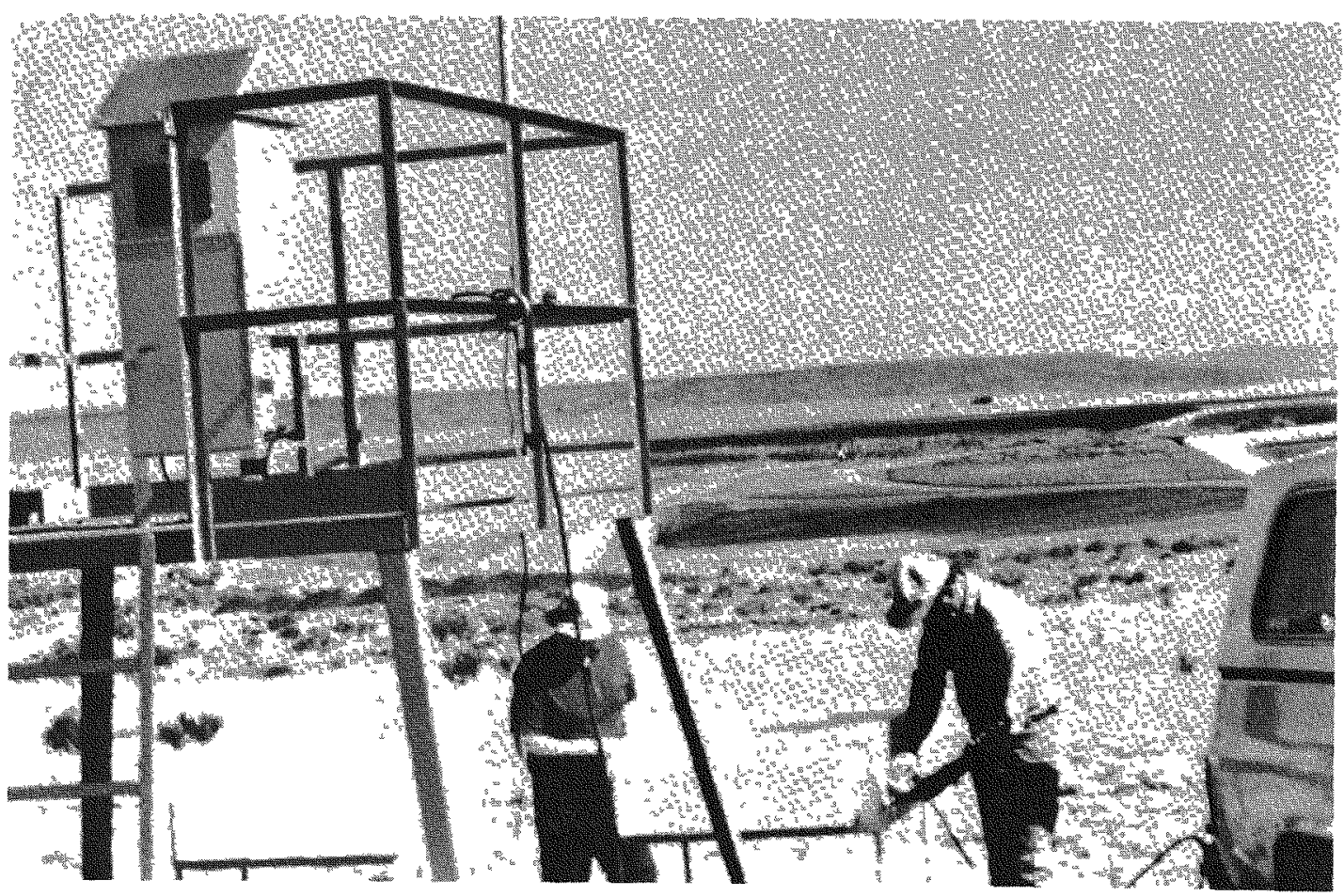

Figure 10. Photo of Representative Sampling Station.

during October 1977 and January through March of 1978. It appears that the airborne concentration of U-238 increased after 1977.

The average airborne concentrations $\left(\mathrm{pCi} / \mathrm{m}^{3}\right)$ of $\mathrm{Th}-230$ were $1.3 \times 10^{-3}$, $5.5 \times 10^{-3}$, and $1.2 \times 10^{-3}$ at stations 102 , 103, and 104. The ranges of measured thorium concentrations $\left(\mathrm{pCi} / \mathrm{m}^{3}\right)$ were $2.69 \times 10^{-4}$ to $3.86 \times 10^{-3}$ (14.3-fold change) at station $102,9.51 \times 10^{-4}$ to $1.23 \times 10^{-2}(12.9$-fold) at station 103 , and $4.46 \times 10^{-4}$ to $2.65 \times 10^{-3}(5.9$-fold) at station 104 . The thorium concentrations measured at these stations are shown in Figure 12 . In contrast to what was observed for U-238, thorium concentration did not seem to increase after 1977, but the maximum and minimum Th-230 concentrations followed the trend of the U-238 concentrations (Fig. 11).

For Ra-226, the average airborne concentrations $\left(\mathrm{pCi} / \mathrm{m}^{3}\right)$ were $3.3 \times 10^{-3}$, $7.3 \times 10^{-3}$, and $1.3 \times 10^{-3}$ at stations 102,103 , and 104 , respectively. The ranges of concentrations $\left(\mathrm{pCi} / \mathrm{m}^{3}\right)$ were $2.72 \times 10^{-4}$ to $1.64 \times 10^{-2}(60.3-\mathrm{fold}$ change) for station $102,1.53 \times 10^{-3}$ to $1.77 \times 10^{-2}(11.6$-fold) for station 103 , and $3.67 \times 10^{-4}$ to $3.35 \times 10^{-3}(9.1$-fold $)$ for station 104 . The profile of distribution of the Ra-226 concentration with time is shown in Figure 13. The pattern is similar for the three stations. The periods of maximum and minimum concentrations of Ra-226 corresponded to those of U-238 and $\mathrm{Th}-230$, except for November and December 1977 and January 1978. During those periods, the concentrations increased at station 103 and decreased at stations 102 and 104. No change in airborne Th-230 concentration was observed after 1977. 
Table 2. Radionuclide Concentrations $\left(\mathrm{pCi} / \mathrm{m}^{3}\right.$ ) in Air Measured at Station 102 Using Continuous Collection Method

\begin{tabular}{|c|c|c|c|c|}
\hline \multirow{2}{*}{$\begin{array}{l}\text { Collection } \\
\text { Period }\end{array}$} & \multicolumn{4}{|c|}{ Concentration \pm Standard Error ${ }^{a}$} \\
\hline & $\mathrm{U}-238$ & $\mathrm{Th}-230$ & $\mathrm{Ra}-226$ & $\mathrm{~Pb}-210$ \\
\hline \multicolumn{5}{|l|}{1977} \\
\hline $\begin{array}{l}6 / 27-7 / 1 \\
7 / 1-7 / 29 \\
7 / 29-9 / 2 \\
9 / 2-9 / 30 \\
9 / 30-10 / 28 \\
10 / 28-12 / 1 \\
12 / 1-12 / 6\end{array}$ & 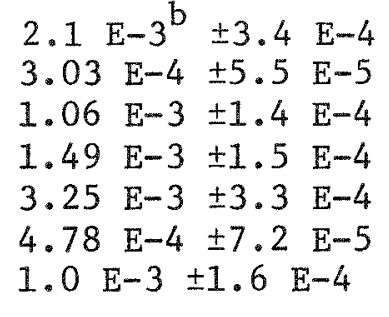 & $\begin{array}{l}1.70 \mathrm{E}-3 \pm 3.9 \mathrm{E}-4 \\
1.2 \mathrm{E}-3 \pm 1.2 \mathrm{E}-4 \\
5.19 \mathrm{E}-4 \pm 6.23 \mathrm{E}-5 \\
5.16 \mathrm{E}-4 \pm 9.1 \quad \mathrm{E}-5 \\
3.86 \mathrm{E}-3 \pm 4.63 \quad \mathrm{E}-4 \\
2.69 \mathrm{E}-4 \pm 7.27 \quad \mathrm{E}-5 \\
2.96 \mathrm{E}-4 \pm 1.5 \mathrm{E}-4\end{array}$ & $\begin{array}{llll}1.74 & \mathrm{E}-3 & \pm 4.0 & \mathrm{E}-4 \\
1.86 & \mathrm{E}-3 & \pm 1.3 & \mathrm{E}-4 \\
6.07 & \mathrm{E}-4 & \pm 7.3 & \mathrm{E}-5 \\
1.97 & \mathrm{E}-3 & \pm 2.6 & \mathrm{E}-4 \\
7.85 & \mathrm{E}-3 & \pm 8.63 & \mathrm{E}-4 \\
1.26 & \mathrm{E}-3 & \pm 1.8 & \mathrm{E}-4 \\
3.42 & \mathrm{E}-4 & \pm 1.54 & \mathrm{E}-4\end{array}$ & $\begin{array}{l}2.10 \mathrm{E}-2 \pm 4.4 \mathrm{E}-3 \\
1.75 \mathrm{E}-2 \quad \pm 1.1 \mathrm{E}-3 \\
1.55 \mathrm{E}-2 \pm 1.6 \mathrm{E}-3 \\
1.53 \mathrm{E}-2 \pm 1.7 \mathrm{E}-3 \\
7.6 \mathrm{E}-2 \pm 7.6 \quad \mathrm{E}-3 \\
1.09 \mathrm{E}-2 \pm 1.2 \quad \mathrm{E}-3 \\
1.68 \mathrm{E}-2 \pm 1.85 \mathrm{E}-3\end{array}$ \\
\hline \multicolumn{5}{|l|}{1978} \\
\hline $\begin{array}{l}12 / 16-1 / 30 \\
1 / 30-2 / 10 \\
4 / 28-5 / 19\end{array}$ & $\begin{array}{llll}2.07 & \mathrm{E}-3 & \pm 2.1 & \mathrm{E}-4 \\
4.17 & \mathrm{E}-3 & \pm 4.6 & \mathrm{E}-4 \\
6.37 & \mathrm{E}-3 & \pm 6.4 & \mathrm{E}-4\end{array}$ & $\begin{array}{llll}2.45 & \mathrm{E}-4 & \pm 4.9 & \mathrm{E}-5 \\
3.27 & \mathrm{E}-4 & \pm 1.5 & \mathrm{E}-4 \\
3.70 & \mathrm{E}-3 & \pm 3.7 & \mathrm{E}-4\end{array}$ & $\begin{array}{llll}2.72 & \mathrm{E}-4 & \pm 6.5 & \mathrm{E}-5 \\
9.03 & \mathrm{E}-4 & \pm 2.4 & \mathrm{E}-4 \\
1.64 & \mathrm{E}-2 & \pm 1.64 & \mathrm{E}-3\end{array}$ & $\begin{array}{llll}1.47 & \mathrm{E}-2 & \pm 1.5 & \mathrm{E}-3 \\
3.74 & \mathrm{E}-2 & \pm 3.7 & \mathrm{E}-3 \\
4.15 & \mathrm{E}-2 & \pm 4.2 & \mathrm{E}-3\end{array}$ \\
\hline Average & $2.2 \mathrm{E}-3 \pm 3.1 \mathrm{E}-4^{\mathrm{a}}$ & $1.3 E-3 \pm 2.4 E-4$ & $3.3 \mathrm{E}-3 \pm 6.0 \mathrm{E}-4$ & $2.7 \mathrm{E}-2 \pm 3.4 \mathrm{E}-3$ \\
\hline
\end{tabular}

analytical error for estimation of concentration.

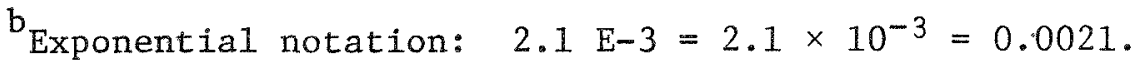


Table 3. Radionuclide Concentrations $\left(\mathrm{pCi} / \mathrm{m}^{3}\right)$ in Air Measured at Station 103 Using Continuous Collection Method

\begin{tabular}{|c|c|c|c|c|}
\hline \multirow{2}{*}{$\begin{array}{l}\text { Collection } \\
\text { Period }\end{array}$} & \multicolumn{4}{|c|}{ Concentration \pm Standard Error ${ }^{a}$} \\
\hline & $\mathrm{U}-238$ & Th-230 & $\mathrm{Ra}-226$ & $\mathrm{~Pb}-210$ \\
\hline \multicolumn{5}{|l|}{1977} \\
\hline $\begin{array}{l}6 / 27-7 / 1 \\
7 / 1-7 / 29 \\
7 / 29-9 / 2 \\
9 / 2-9 / 30 \\
9 / 30-10 / 28 \\
10 / 28-12 / 1 \\
12 / 1-12 / 16\end{array}$ & 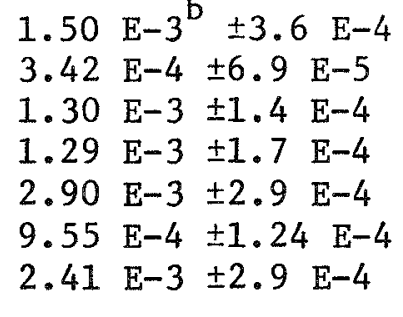 & 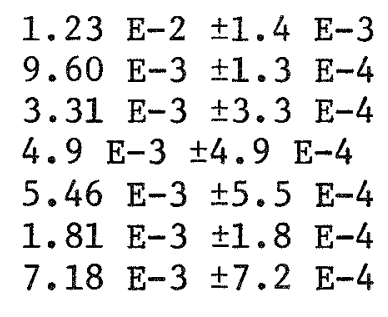 & $\begin{array}{llll}1.27 & \mathrm{E}-2 & \pm 1.5 & \mathrm{E}-3 \\
4.29 & \mathrm{E}-3 & \pm 4.3 & \mathrm{E}-4 \\
2.66 & \mathrm{E}-3 & \pm 2.7 & \mathrm{E}-4 \\
6.67 & \mathrm{E}-3 & \pm 6.7 & \mathrm{E}-4 \\
6.72 & \mathrm{E}-3 & \pm 6.7 & \mathrm{E}-4 \\
4.02 & \mathrm{E}-3 & \pm 4.0 & \mathrm{E}-4 \\
1.77 & \mathrm{E}-2 & \pm 1.8 & \mathrm{E}-3\end{array}$ & $\begin{array}{llll}2.0 & \mathrm{E}-2 & \pm 6 & \mathrm{E}-3 \\
1.49 & \mathrm{E}-2 & \pm 1.5 & \mathrm{E}-3 \\
1.87 & \mathrm{E}-2 & \pm 1.9 & \mathrm{E}-3 \\
2.25 & \mathrm{E}-2 & \pm 2.3 & \mathrm{E}-3 \\
3.55 & \mathrm{E}-2 & \pm 3.6 & \mathrm{E}-3 \\
1.93 & \mathrm{E}-2 & \pm 1.9 & \mathrm{E}-3 \\
3.97 & \mathrm{E}-2 & \pm 4.0 & \mathrm{E}-3\end{array}$ \\
\hline \multicolumn{5}{|l|}{1978} \\
\hline $\begin{array}{l}12 / 16-1 / 30 \\
1 / 30-2 / 10\end{array}$ & $\begin{array}{llll}2.60 & \mathrm{E}-3 & \pm 2.6 & \mathrm{E}-4 \\
2.86 & \mathrm{E}-3 & \pm 3.7 & \mathrm{E}-4\end{array}$ & $\begin{array}{llll}3.85 & E-3 & \pm 3.9 & E-4 \\
9.51 & E-4 & \pm 2.3 & E-4\end{array}$ & $\begin{array}{llll}9.74 & \mathrm{E}-3 & \pm 9.8 & \mathrm{E}-4 \\
1.53 & \mathrm{E}-3 & \pm 3.1 & \mathrm{E}-4\end{array}$ & $\begin{array}{llll}2.34 & \mathrm{E}-2 & \pm 2.3 & \mathrm{E}-3 \\
2.28 & \mathrm{E}-2 & \pm 3.2 & \mathrm{E}-3\end{array}$ \\
\hline Average & $1.8 \mathrm{E}-3 \pm 2.5 \mathrm{E}-4^{\mathrm{a}}$ & $5.5 \mathrm{E}-3 \pm 6.0 \mathrm{E}-4$ & $7.3 \mathrm{E}-3 \pm 9.3 \mathrm{E}-4$ & $2.4 E-2 \pm 3.3 E-3$ \\
\hline
\end{tabular}

analytical error for estimation of the concentration.

${ }^{b}$ Exponential notation: $1.50 \mathrm{E}-3=1.50 \times 10^{-3}=0.00150$. 
Table 4. Radionuclide Concentrations $\left(\mathrm{pCi} / \mathrm{m}^{3}\right)$ in Air Measured at Station 104 Using Continuous Collection Method

\begin{tabular}{|c|c|c|c|c|}
\hline \multirow{2}{*}{$\begin{array}{l}\text { Collection } \\
\text { Period }\end{array}$} & \multicolumn{4}{|c|}{ Concentration \pm Standard Error ${ }^{a}$} \\
\hline & $\mathrm{U}-238$ & $\mathrm{Th}-230$ & $\mathrm{Ra}-226$ & $\mathrm{~Pb}-210$ \\
\hline \multicolumn{5}{|l|}{1977} \\
\hline $\begin{array}{l}6 / 27-7 / 1 \\
7 / 1-7 / 29 \\
7 / 29-9 / 2 \\
9 / 2-9 / 30 \\
9 / 30-10 / 28 \\
10 / 28-11 / 4 \\
11 / 4-12 / 6\end{array}$ & 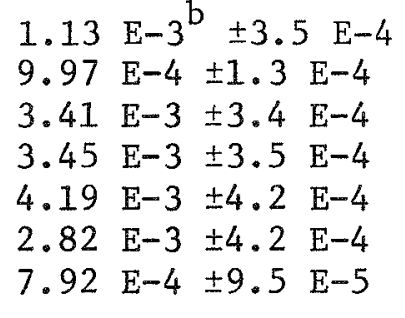 & $\begin{array}{llll}1.25 & \mathrm{E}-3 & \pm 4 & \mathrm{E}-4 \\
2.65 & \mathrm{E}-3 & \pm 5.3 & \mathrm{E}-4 \\
5.49 & \mathrm{E}-4 & \pm 8.8 & \mathrm{E}-5 \\
4.46 & \mathrm{E}-4 & \pm 8.9 & \mathrm{E}-5 \\
1.76 & \mathrm{E}-3 & \pm 1.9 \quad \mathrm{E}-4 \\
1.19 & \mathrm{E}-3 & \pm 3.78 \quad \mathrm{E}-4 \\
1.28 & \mathrm{E}-3 & \pm 1.4 \quad \mathrm{E}-4\end{array}$ & $\begin{array}{llll}1.91 & \mathrm{E}-3 & \pm 5.9 & \mathrm{E}-4 \\
3.35 & \mathrm{E}-3 & \pm 3.4 & \mathrm{E}-4 \\
5.29 & \mathrm{E}-4 & \pm 1.0 & \mathrm{E}-4 \\
9.00 & \mathrm{E}-4 & \pm 1.35 & \mathrm{E}-4 \\
1.95 & \mathrm{E}-3 \pm 2.3 & \mathrm{E}-4 \\
& -\mathrm{c} \\
3.67 & \mathrm{E}-4 \pm 6.6 & \mathrm{E}-5\end{array}$ & 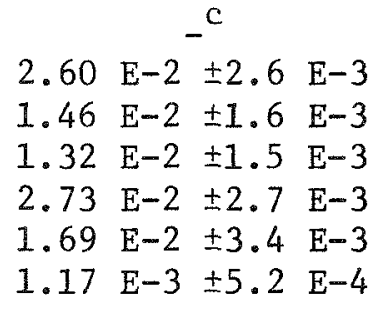 \\
\hline \multicolumn{5}{|l|}{1978} \\
\hline $\begin{array}{l}12 / 16-1 / 30 \\
1 / 30-2 / 10\end{array}$ & 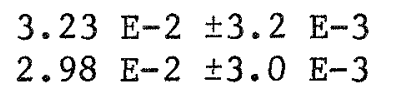 & $\begin{array}{llll}1.07 & \mathrm{E}-3 & \pm 1.2 & \mathrm{E}-4 \\
9.03 & \mathrm{E}-4 & \pm 2.3 & \mathrm{E}-4\end{array}$ & $\begin{array}{llll}8.71 & E-4 & \pm 1.1 & E-4 \\
7.64 & E-4 & \pm 2.2 & E-4\end{array}$ & $\begin{array}{llll}1.75 & \mathrm{E}-2 & \pm 1.8 & \mathrm{E}-3 \\
3.78 & \mathrm{E}-2 & \pm 3.8 & \mathrm{E}-3\end{array}$ \\
\hline Average & $8.8 \mathrm{E}-3 \pm 1.5 \mathrm{E}-3^{\mathrm{a}}$ & $1.2 \mathrm{E}-3 \pm 2.8 \mathrm{E}-4$ & $1.3 \mathrm{E}-3 \pm 2.6 \mathrm{E}-4$ & $1.4 \mathrm{E}-2 \pm 2.3 \mathrm{E}-3$ \\
\hline
\end{tabular}

${ }^{a}$ Analytical error for estimation of the concentration.

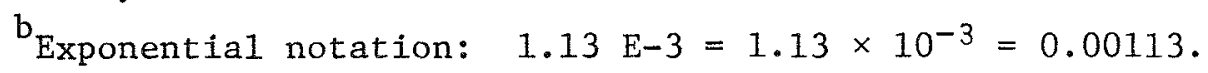

$\mathrm{c}_{\text {Not measured. }}$ 


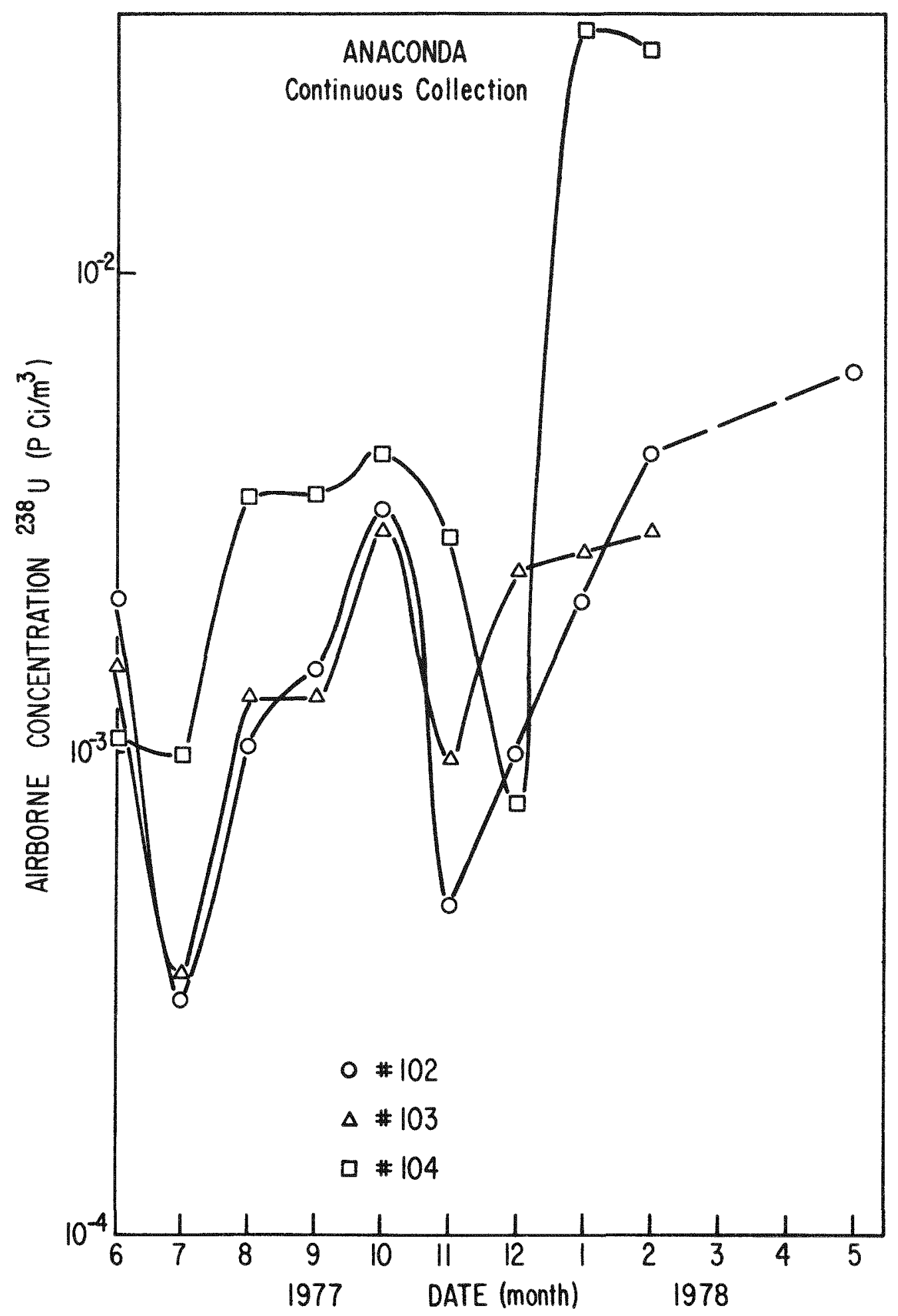

Figure 11. Airborne Concentrations of U-238 as Measured by Continuous Collection Method. 


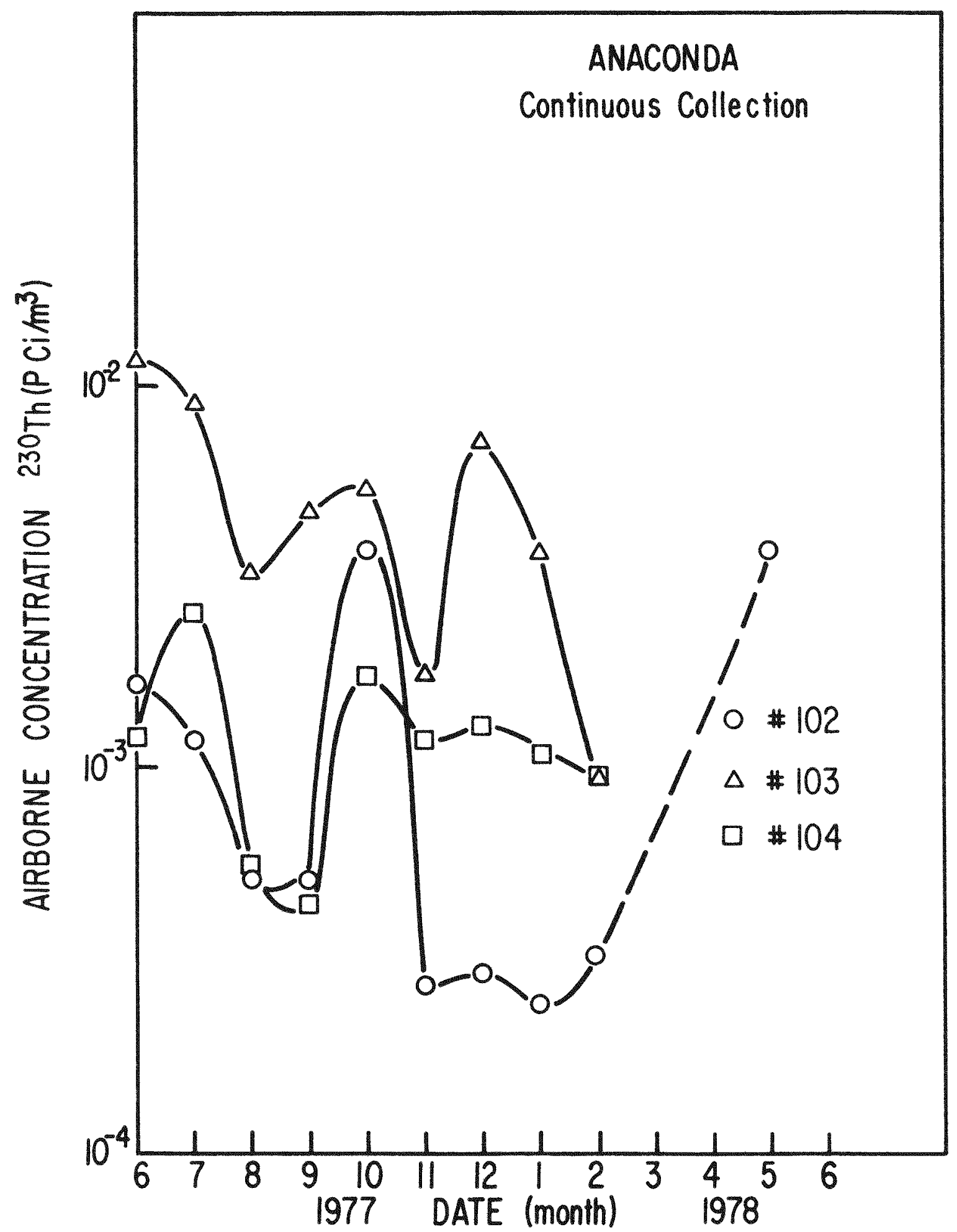

Figure 12. Airborne Concentrations of Th-230 as Measured by Continuous Collection Method. 


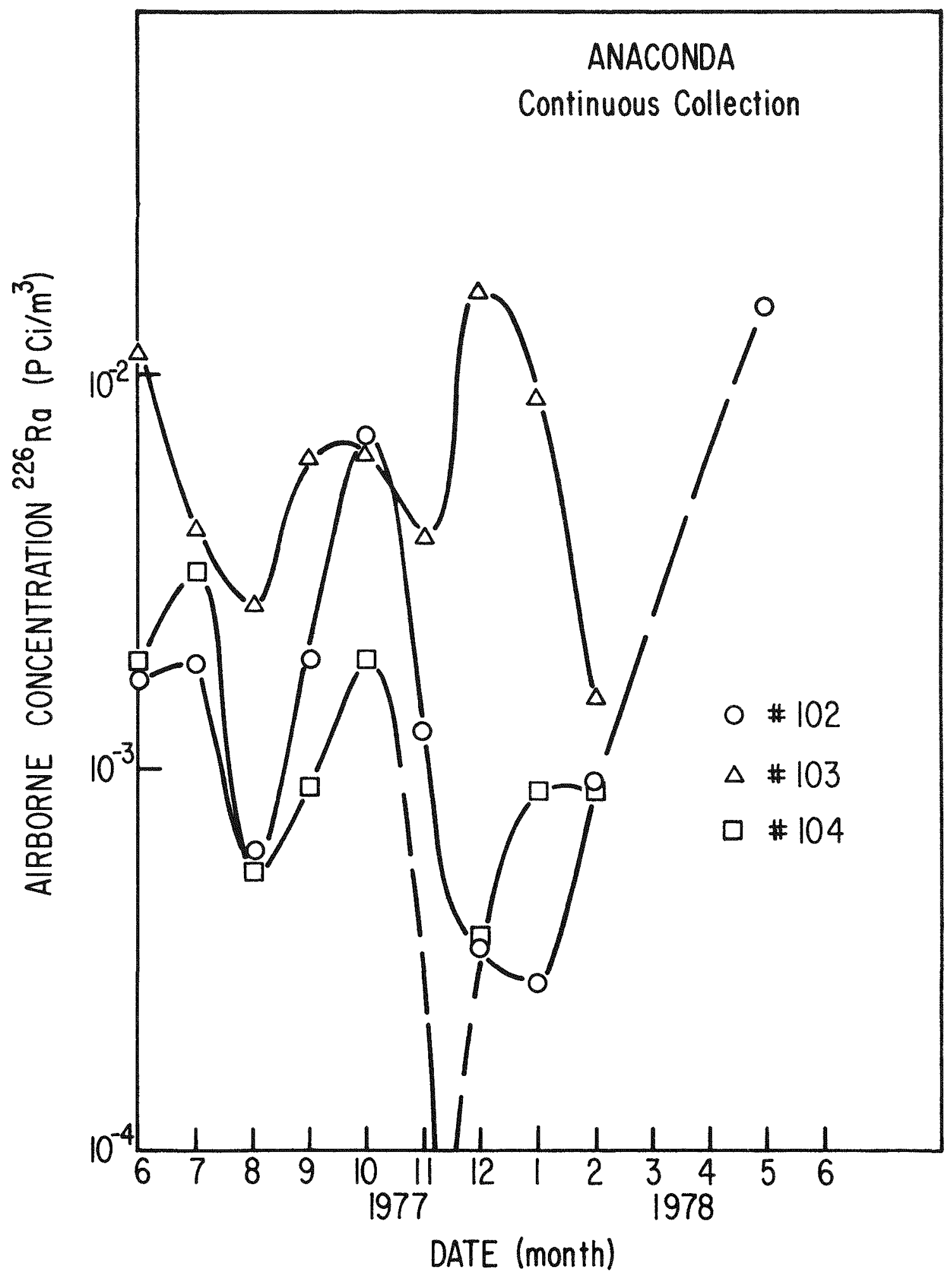

Figure 13. Airborne Concentrations of Ra-226 as Measured by Continuous Collection Method. 
The average $\mathrm{Pb}-210$ concentration $\left(\mathrm{pCi} / \mathrm{m}^{3}\right.$ ) was $2.7 \times 10^{-2}$ (range $1.09 \times 10^{-2}$ to $7.6 \times 10^{-2}$ ) at station $102,2.4 \times 10^{-2}$ (range $1.49 \times 10^{-2}$ to $3.97 \times 10^{-2}$ ) at station 103 , and $1.4 \times 10^{-2}$ (range $1.17 \times 10^{-3}$ to $3.78 \times 10^{-2}$ ) at station 104. The changes in $\mathrm{Pb}-210$ concentration with time are shown in Figure 14.

The average concentrations of $\mathrm{Th}-230, \mathrm{Ra}-226$, and $\mathrm{Pb}-210$ normalized to the average concentration of U-238 for each station are given in Table 5 . In all cases, the concentration of $\mathrm{Pb}-210$ exceeded that of $\mathrm{U}-238$, but only at station 103 was the concentration of Th-230 larger than the concentration of $\mathrm{U}-238$. The concentration of $\mathrm{Ra}-226$ also was larger than that of $\mathrm{U}-238$ at stations 102 and 103. Because the major source of airborne U-238 is the drying and packaging operations (Momeni et a1. 1979b) and because our measurements suggest secular radioactive equilibrium in the ore, the data in Table 5 seem to indicate that the dominant source of Th-230 and Ra-226 measured at station 103 was the tailings pile. With respect to station 102 , the Ra-226 concentration seems to be dominated by the tailings, where the U-238 concentration is a fraction of the Ra-226 concentration. However, in light of the variability of these data with respect to time, the suggested correlation between the sources and the concentrations is highly speculative. A detailed analysis of the correlation between each source and the concentration would have to include consideration of a variety of atmospheric and climatic factors and is beyond the scope of this report. Again, comparison between the measured concentrations and theoretical predictions will be reported elsewhere.

The major source of airborne $\mathrm{Pb}-210$ is from decay of $\mathrm{Rn}-222$ present in the atmosphere. Other sources of $\mathrm{Pb}-210$ in the air are the ore as a result of direct release during milling operations, and the ore pad and tailings by means of resuspension. The ratios of airborne concentrations of $\mathrm{Pb}-210$ to U-238 at stations 102, 103, and 104, respectively, were $12.3,13.3$ and 1.6 (Table 5). The ratio at station 104, the closest station to the mil1, suggests a strong contribution of uranium from the yellowcake stack.

Table 5. Concentrations of Airborne Radionuclides Normalized to Uranium Concentration as Measured by Continuous Collection Method

\begin{tabular}{lccc}
\hline Ratio & Station 102 & Station 103 & Station 104 \\
\hline $\mathrm{Th}-230 / \mathrm{U}-238$ & 0.6 & 3.1 & 0.14 \\
$\mathrm{Ra}-226 / \mathrm{U}-238$ & 1.5 & 4.1 & 0.15 \\
$\mathrm{~Pb}-210 / \mathrm{U}-238$ & 12.3 & 13.3 & 1.6 \\
\hline
\end{tabular}




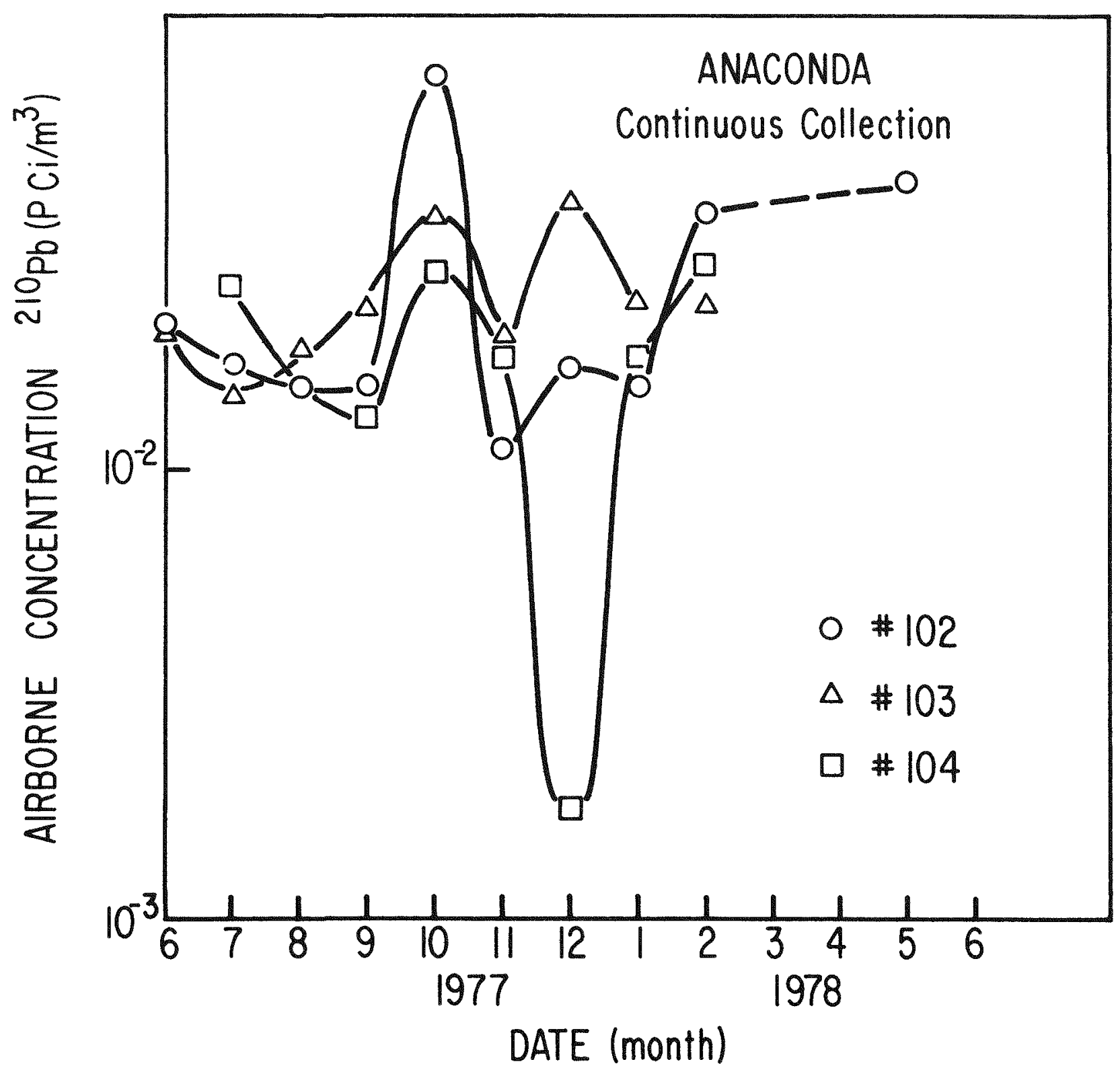

Figure 14. Airborne Concentrations of $\mathrm{Pb}-210$ as Measured by Continuous Collection Method. 
High Volume Sampling

Airborne concentrations of U-238, Th-230, Ra-226, and $\mathrm{Pb}-210$ were sampled using Andersen "Hi Vol" samplers with a flow rate of $1400 \pm 150 \mathrm{~L} / \mathrm{min}$ at stations 100, 101, 104 and 105. The concentrations (and the standard error of analytical measurements) are given in Tables 6 through 9. Because of the short collection periods ( 24 to 48 hours), the average concentrations calculated from the samples may not be representative of the true monthly averages. Detailed comparison of the measured concentrations with meteorological parameters will be reported elsewhere.

The average gravimetric particulate concentrations are given in Tables 6 through 9 for the selected periods of measurement. The average particulate concentration was $74.4 \pm 8.2 \mu \mathrm{g} / \mathrm{m}^{3}$ during the period $1-5$ August 1977 at station 100. At station 101 the average concentration was $41.6 \pm 8.1 \mathrm{\mu g} / \mathrm{m}^{3}$ (range of 30 to $48.9 \mu \mathrm{g} / \mathrm{m}^{3}$ ) for August to October 1977 (Table 7). At station 104 the average concentration was $54.8 \pm 8.7 \mu \mathrm{g} / \mathrm{m}^{3}$ (range of 44.4 to $65.3 \mu \mathrm{g} / \mathrm{m}^{3}$ ) for September and October 1977 (Table 8). The lowest concentration was measured at station 105, with an average of $25.0 \pm 5.4 \mu \mathrm{g} / \mathrm{m}^{3}$ (range of 16.7 to $33.2 \mu \mathrm{g} / \mathrm{m}^{3}$ ) (Table 9). Station 105 is $7 \mathrm{~m}$ above the ground, whereas the other stations are only $3 \mathrm{~m}$ aboveground. In addition, station 105 is farther from the mill site and the tailings (Fig. 2) than the other stations. These two factors may partially explain the lower observed particulate concentration at station 105. These concentrations were recorded for periods of average wind speed and the average thus derived may be less than the seasonal average. In comparison with the reported gravimetric concentrations of about $100 \mu \mathrm{g} / \mathrm{m}^{3}$ in urban areas (NCRP \#45 1975) and about $50 \mathrm{\mu g} / \mathrm{m}^{3}$ in the unpolluted air, the average airborne particulate concentration measured at the Anaconda site does not seem to be elevated.

Average airborne concentration of U-238 at station 100 between June 1977 and Apri1 1978 was $9.2 \times 10^{-3} \mathrm{pCi} / \mathrm{m}^{3}$, with a range of $9.4 \times 10^{-4}$ to $2.17 \times 10^{-2} \mathrm{pCi} / \mathrm{m}^{3}$. This range corresponds to a 23-fold change in uranium concentration. The average concentrations of U-238 at stations 101,104 , and 105, respectively, were $2.2 \times 10^{-3}, 1.1 \times 10^{-2}$, and $1.2 \times 10^{-3} \mathrm{pCi} / \mathrm{m}^{3}$. The ranges in concentrations $\left(\mathrm{pCi} / \mathrm{m}^{3}\right)$ were $6.47 \times 10^{-4}$ to $5.08 \times 10^{-3}(8.6$-fold change) at station $101,7.4 \times 10^{-4}$ to $4.33 \times 10^{-2}(58.5$-fold) at station 104, and $4.31 \times 10^{-4}$ to $2.52 \times 10^{-3}(5.8$-fold) at station 105 . The variation of average U-238 concentrations with time is shown in Figure 15. Comparison of the change in concentration among the stations does not show a common pattern as was observed for data from the continuous mode of particle collection. Station 105 is farther from the mill and the tailings than the other stations; therefore a lower airborne concentration of U-238 at this station may reflect the additional distance from the sources of release.

The distribution of the average airborne concentrations of Th-230, Ra-226, and $\mathrm{Pb}-210$ as a function of the collection date is shown in Figures 16 through 18. The pattern at station 101 was similar for all the radionuclides, with a period of high concentration during July 1977. Th-230 concentration peaked in July at this station, but it decreased at all other stations (Fig. 16). It appeared that for a11 stations the changes in concentration of $\operatorname{Ra}-226$ (Fig. 17) were similar between June and October 1977. After 1977, the profiles for stations 100 and 104 seemed to be similar for Th-230 and Ra-226. At stations 101 
Table 6. Radionuclide Concentrations $\left(\mathrm{pCi} / \mathrm{m}^{3}\right)$ in Air Measured at Station 100 Using High Volume Sampler

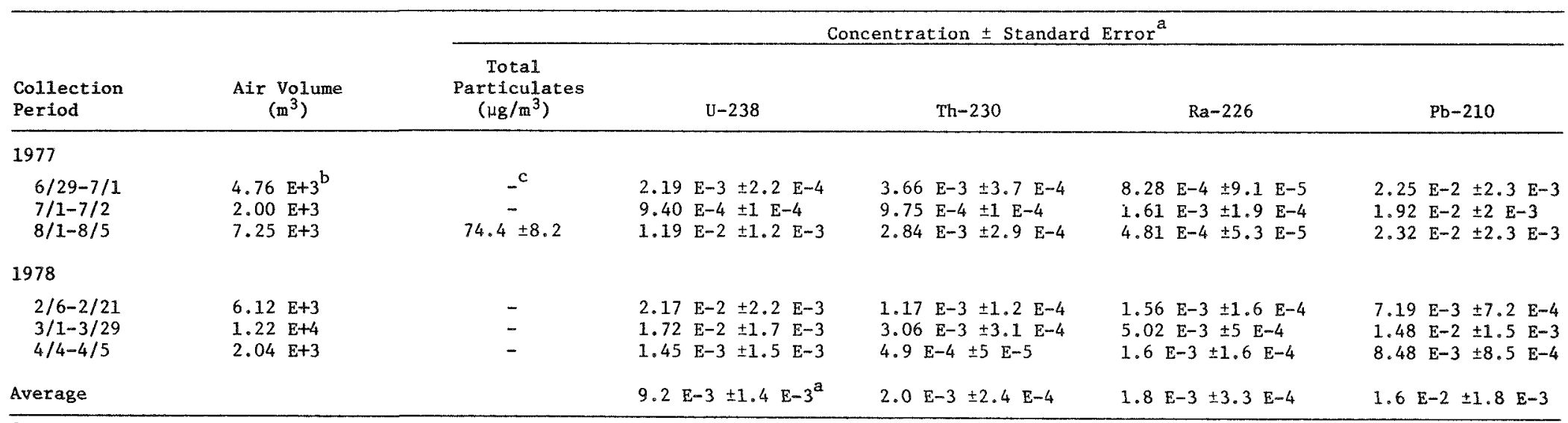

Analytical exror for estimation of the concentration.

Exponential notation: $4.76 \mathrm{E}+3=4.76 \times 10^{3}=4760$.

Not measured.

Table 7. Radionuclide Concentrations $\left(\mathrm{pCi} / \mathrm{m}^{3}\right)$ in Air Measured at Station 101 Using High Volume Sampler

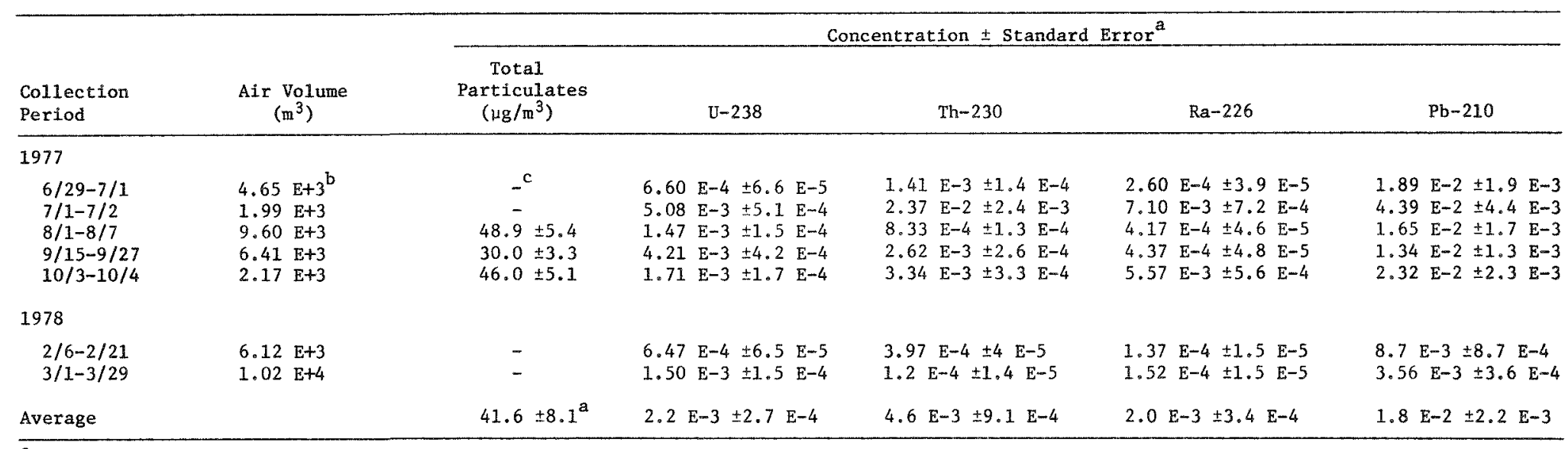

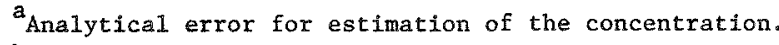

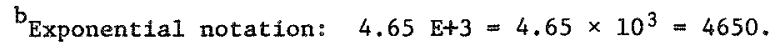

${ }^{\mathrm{C}}$ Not measured. 
Table 8. Radionuclide Concentrations $\left(\mathrm{pCi} / \mathrm{m}^{3}\right)$ in Air Measured at Station 104 Using High Volume Sampler

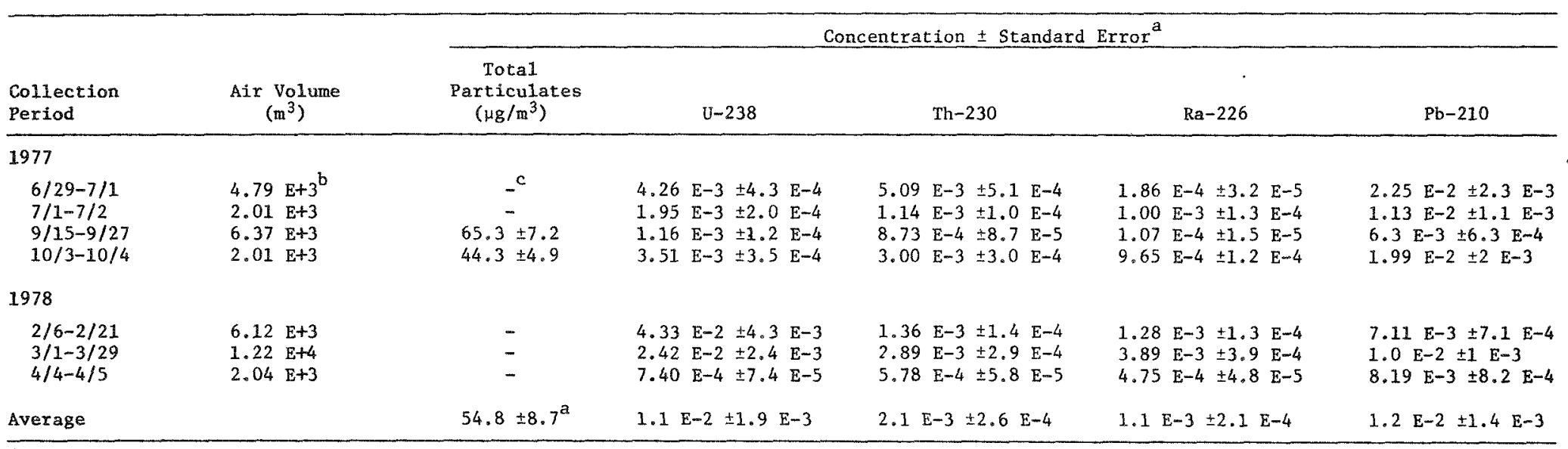

Analytical error for estimation of the concentration.

Exponential notation: $4.79 \mathrm{E}+3=4.79 \times 10^{3}=4790$.

$c_{\text {Not measured. }}$

Table 9. Radionuclide Concentrations $\left(\mathrm{pCi} / \mathrm{m}^{3}\right)$ in Air Measured at Station 105 Using High Volume Sampler

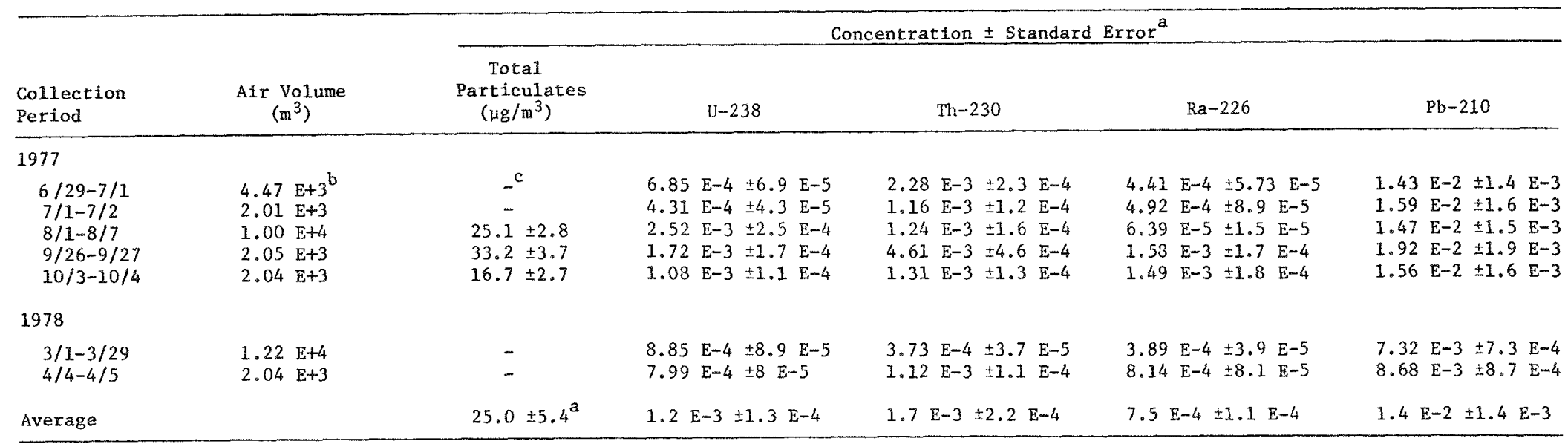

Analytical error for estimation of the concentration.

Exponential notation: $4.47 \mathrm{E}+3=4.47 \times 10^{3}=4470$.

${ }^{c}$ Not measured. 


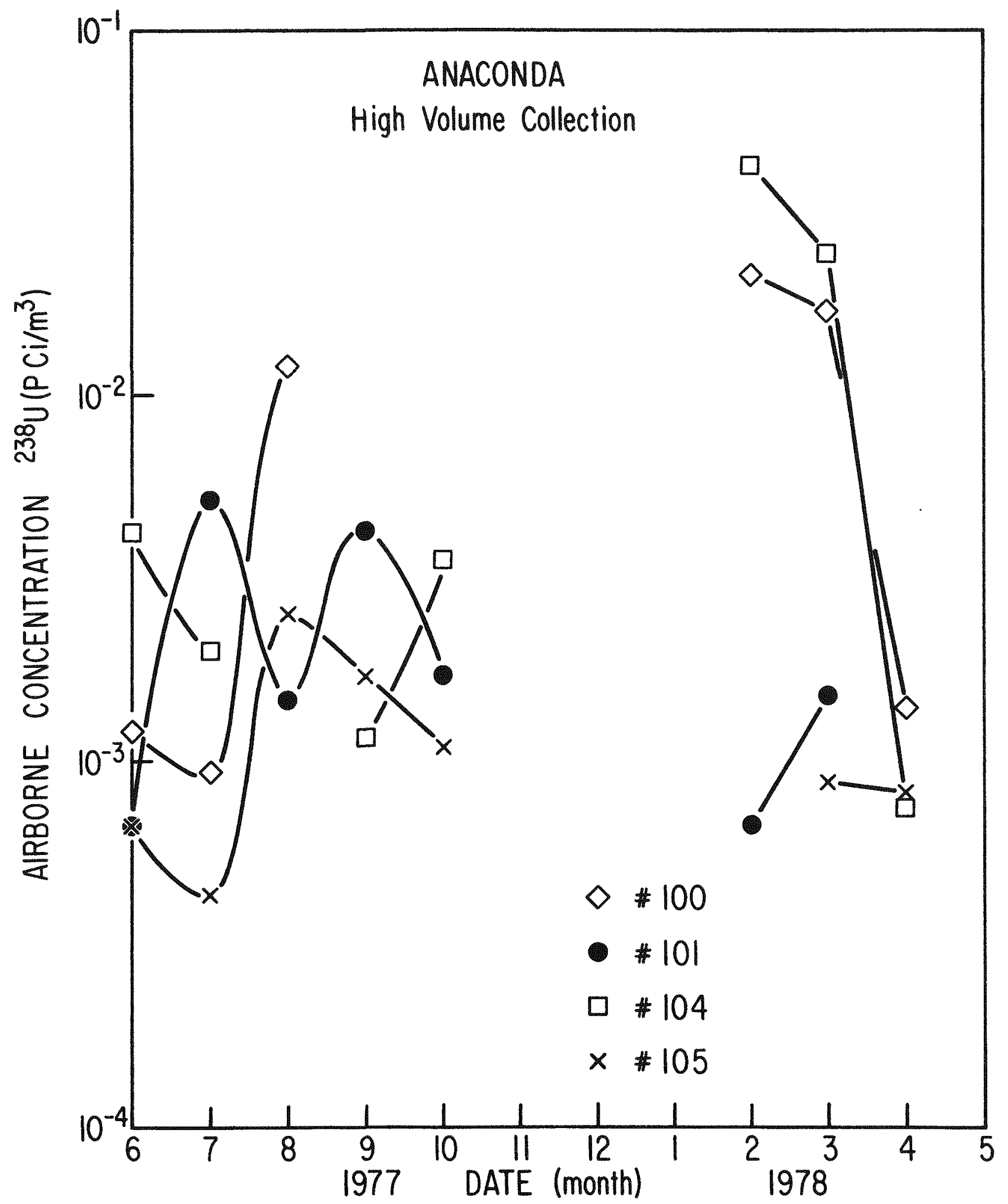

Figure 15. Airborne Concentrations of U-238 as Measured by $\mathrm{High}$ Volume Collection Method. 


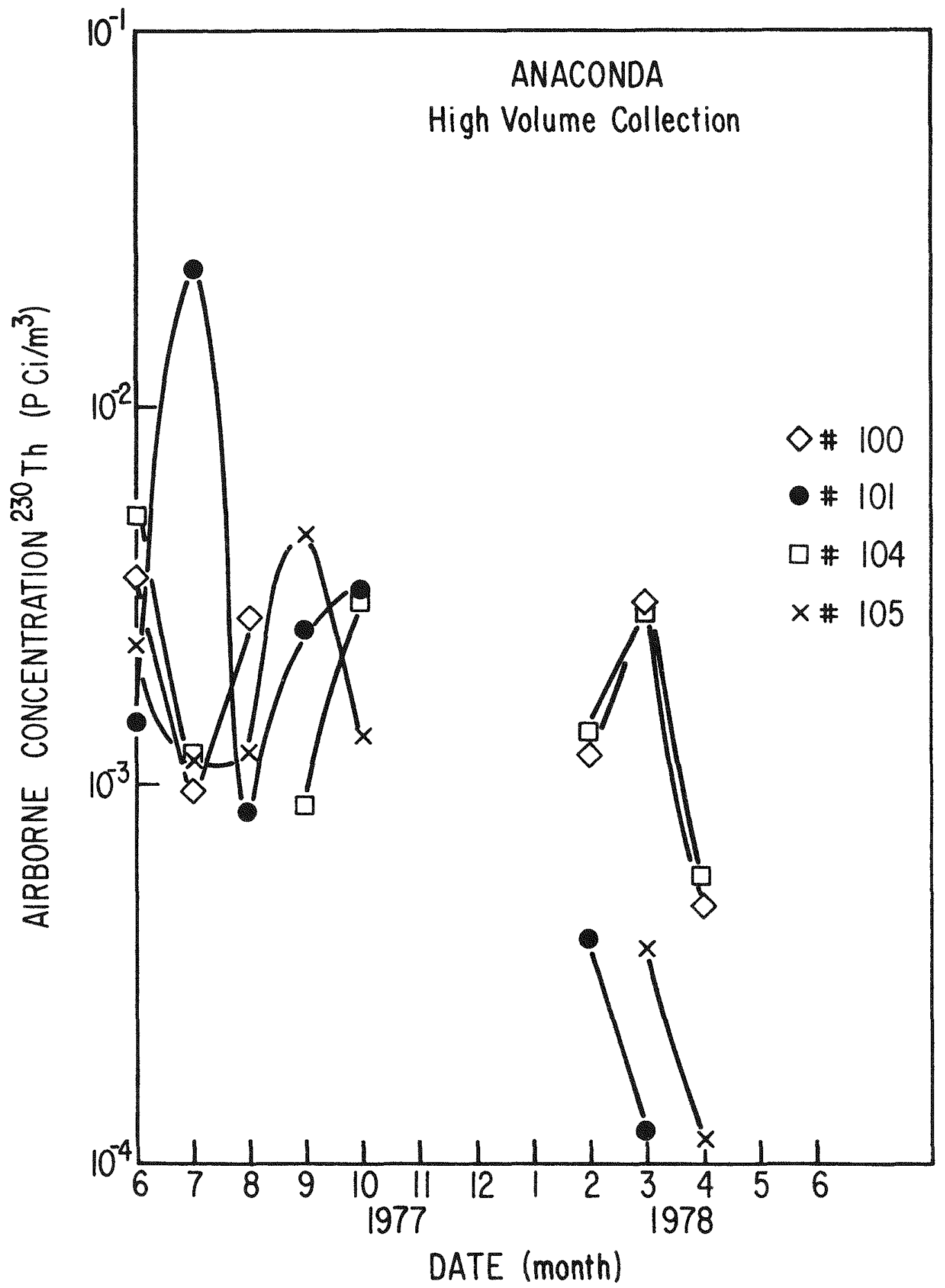

Figure 16. Airborne Concentrations of Th-230 as Measured by High Volume Collection Method. 


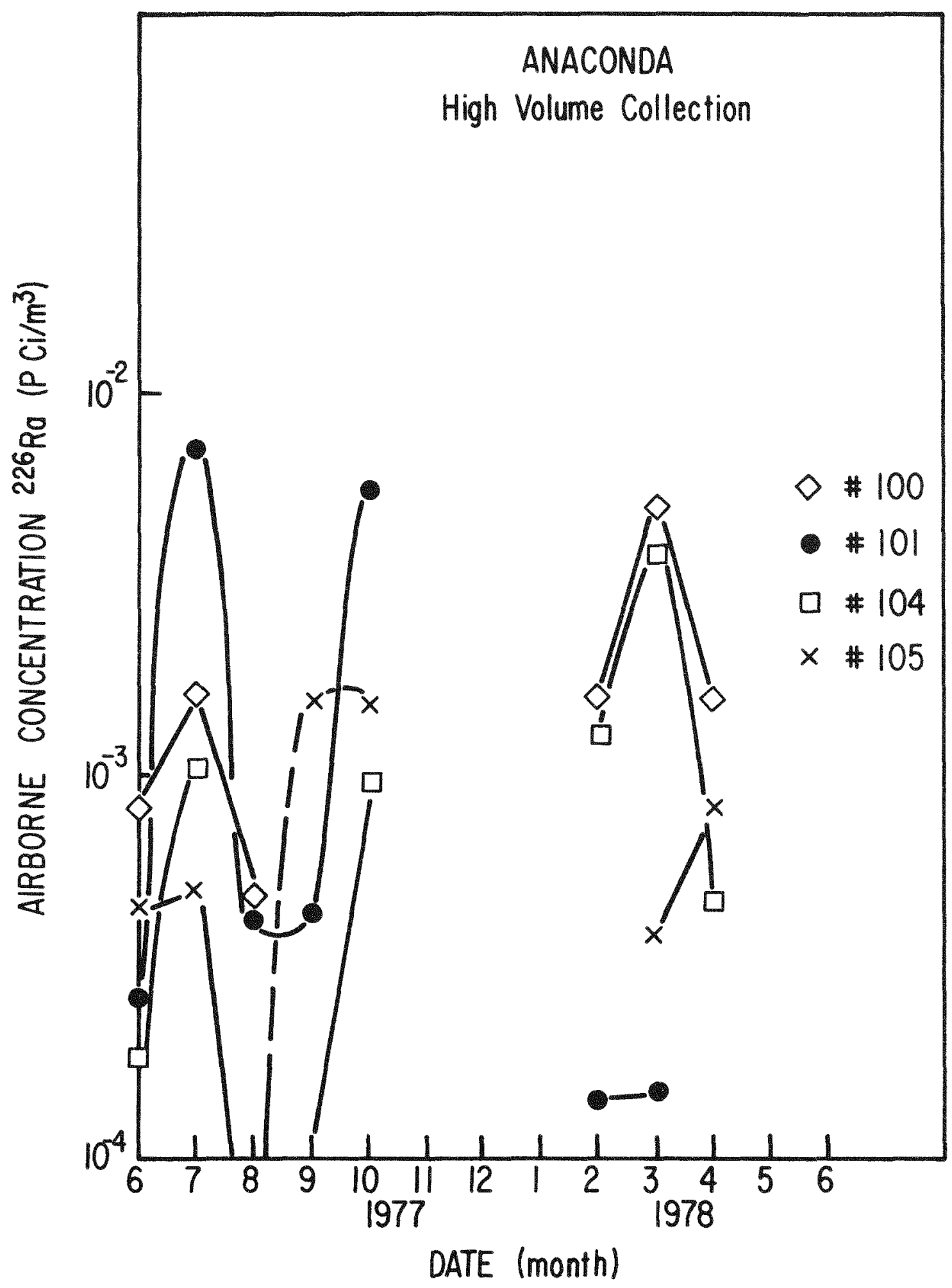

Figure 17. Airborne Concentrations of Ra-226 as Measured by High Volume Collection Method. 


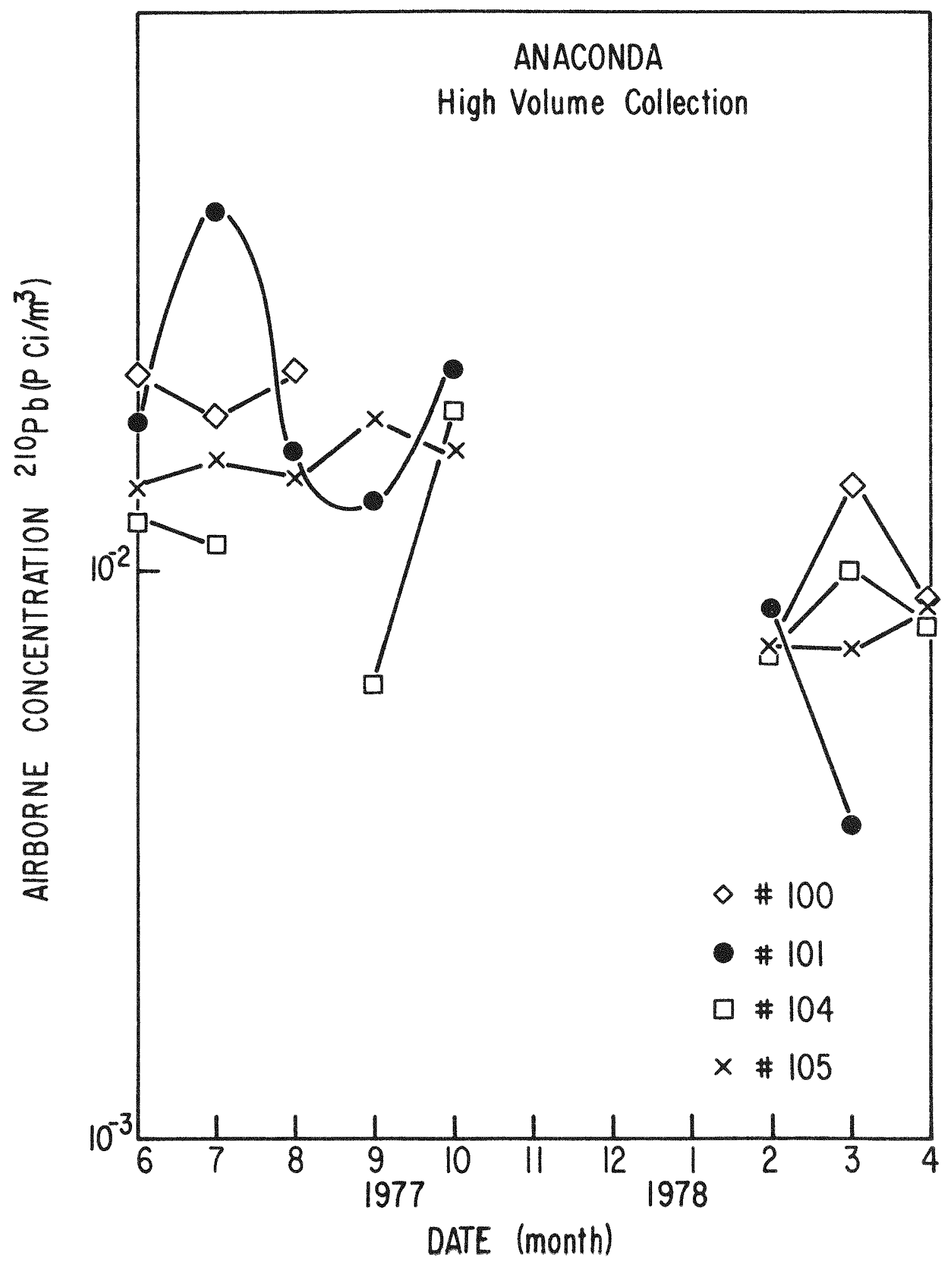

Figure 18. Airborne Concentrations of $\mathrm{Pb}-210$ as Measured by High Volume Collection Method. 
and 105 the same pattern was observed for Th-230 during the period after 1977. Airborne concentration of $\mathrm{Pb}-210$ (Fig. 18) at stations 100 and 105 was nearly constant during 1977 and seemed to be similar to the U-238 concentration distribution (Fig. 15) observed at station 101.

Average airborne concentrations of particulates at the same stations used by our group also were measured by the staff of the Anaconda Uranium Mil1 (Tables 10 and 11). Comparison of these averages with our data (Tables 7 through 9) seems to show a good correspondence between all measurements except that of uranium at station 104. Since contribution of U-238 to the activity of natural uranium is about $50 \%$, the concentrations $3.83 \times 10^{-3}$ and $1.89 \times 10^{-3}$ $\mathrm{pCi} / \mathrm{m}^{3}$ natural uranium measured during 1978 and 1979 by Anaconda personnel at station 104 (Tables 10 and 11) are, respectively, equivalent to about $1.9 \times 10^{-3}$ and $0.95 \times 10^{-3} \mathrm{pCi} \mathrm{U}-238 / \mathrm{m}^{3}$. These are about one order of magnitude less than our value of $1.1 \times 10^{-2} \pm 5 \times 10^{-3} \mathrm{pCi} U-238 / \mathrm{m}^{3}$. The reasou for this difference is not yet known.

Table 10. Average Airborne Concentrations of U-Nat, Th-230, $\mathrm{Ra}-226$, and $\mathrm{Pb}-210$ as Collected by Anaconda Company Using High Volume Air Sampling System for the Last Six Months of $1978^{a}$

\begin{tabular}{|c|c|c|c|c|c|}
\hline \multirow[b]{2}{*}{ Station } & \multirow[b]{2}{*}{ Location } & \multicolumn{4}{|c|}{ Concentration $\left(10^{-3} \mathrm{pCi} / \mathrm{m}^{3}\right)$} \\
\hline & & U-nat & Th-230 & $\mathrm{Ra}-226$ & $\mathrm{~Pb}-210$ \\
\hline 105 & Weather station & 2.65 & 0.16 & 0.16 & 5.59 \\
\hline 100 & Golf course & 4.75 & 0.78 & 0.79 & 7.47 \\
\hline 104 & Sewage plant & 3.83 & 3.18 & 1.88 & 4.13 \\
\hline 101 & Northern perimeter & 1.22 & 0.66 & 0.35 & 8.70 \\
\hline
\end{tabular}


Table 11. Average Airborne Concentrations of U-Nat, Th-230, $\mathrm{Ra}-226$, and $\mathrm{Pb}-210$ as Collected by Anaconda Company Using High Volume Air Sampling System

for the First Six Months of $1979^{a}$

\begin{tabular}{clcccc}
\hline & & \multicolumn{3}{c}{ Concentration } & $\left(10^{-3} \mathrm{pCi} / \mathrm{m}^{3}\right)$ \\
\cline { 3 - 6 } Station & Location & U-nat & Th-230 & $\mathrm{Ra}-226$ & $\mathrm{~Pb}-210$ \\
\hline 105 & Weather station & 2.20 & 0.92 & 1.25 & 4.81 \\
100 & Golf course & 1.62 & 0.82 & 0.85 & 7.47 \\
104 & Sewage plant & 1.89 & 2.51 & 1.57 & 17.28 \\
101 & Northern perimeter & 1.30 & 0.42 & 0.15 & 26.30 \\
\hline
\end{tabular}

arom report to the State of New Mexico by the Anaconda Company.

Comparison of Continuous and High Volume Sampling

The variation in airborne U-238 concentration with time, as measured by the two collection methods, is shown in Figures 11 and 15. Data from stations 101 and 102, located in the northwestern corner of the Anaconda site only about $200 \mathrm{~m}$ apart ( $F i g .2$ ), indicate some differences between the sampling methods. The data collected by the continuous sampling technique suggest a low U-238 concentration during July 1977, while the data collected by the Hi Vol technique suggest a low concentration during August. However, air samples were collected only during the first week of August using the Hi Vol sampler. For both techniques, the minimum concentrations were recorded during the same collection period. Furthermore, the rise and fall in concentrations of U-238 at station 104 during 1978 are comparable for the two methods (Figs. 11 and 15).

The average concentrations and ratios of concentration for U-238, Th-230, $\mathrm{Ra}-226$, and $\mathrm{Pb}-210$ using the two collection techniques are given in Table 12 for stations 101, 102, and 104. At stations 101 and 102, the agreement is satisfactory only for uranium. A major difference in the data is that the duration of $\mathrm{Hi}$ Vol collection may have been too short to represent the actual monthly average concentrations. As data from the continuous collection technique indicate, a wide range of airborne particle concentrations are expected because of climatic and meteorological factors and the dynamic nature of the milling operation. During short collection periods, a 100-fold change in the airborne concentration can be expected because of wind storms. In general, for short periods of 24 to 48 hours, the higher rate of air sampling of the Hi Vol system will provide a better estimate of low particle concentrations than will the continuous collection technique. However, the longer collection period of the continuous method provides samples which are more representative of the average airborne concentrations. In principal, comparisons such as those in Table 12 are fraught with difficulty because of the problem of obtaining a representative sample using a short-duration collection technique. The 
authors recommend that a continuous particulate collection method, composited to a monthly sample, with an air sampling rate of $25 \mathrm{~L} / \mathrm{min}$ or more, would provide both a representative measurement and sufficient sensitivity for detection of low-1evel particulate concentrations.

Table 12. Comparison of Airborne Concentrations of Radionuclides Measured Using Continuous Collection and High Volume Air Sampling Procedures

\begin{tabular}{lcccc}
\hline & \multicolumn{4}{c}{ Average Concentration $\left(\mathrm{pCi} / \mathrm{m}^{3}\right)$} \\
\cline { 4 - 5 } Technique & $\mathrm{U}-238$ & $\mathrm{Th}-230$ & $\mathrm{Ra}-226$ & $\mathrm{~Pb}-210$ \\
\hline Stations 101 and 102 & & & & \\
$\quad$ Continuous & $2.2 \mathrm{E}-3^{\mathrm{a}}$ & $1.3 \mathrm{E}-3$ & $3.3 \mathrm{E}-3$ & $2.7 \mathrm{E}-2$ \\
$\quad$ Hi Vol & $2.2 \mathrm{E}-3$ & $4.6 \mathrm{E}-3$ & $2.0 \mathrm{E}-3$ & $1.8 \mathrm{E}-2$ \\
$\quad$ Ratio (continuous/Hi Vol) & 1.0 & 0.28 & 1.7 & 1.5 \\
Station 104 & & & & \\
$\quad \begin{array}{l}\text { Continuous } \\
\text { Hi Vol } \\
\text { Ratio (continuous/Hi Vol) }\end{array}$ & $1.1 \mathrm{E}-2$ & $2.1 \mathrm{E}-3$ & $1.1 \mathrm{E}-3$ & $1.2 \mathrm{E}-2$ \\
\hline a
\end{tabular}

Exponential notation: $2.2 \mathrm{E}-3=2.2 \times 10^{-3}=0.0022$.

Comparison with Background and Maximum Permissible Concentration

There are wide temporal and spatial variations in background concentrations of radioactive aerosols across the United States. At Argonne National Laboratory near Chicago, Illinois, concentrations of airborne radionuclides were reported by Sedlet et al. (1973) as $1.2 \times 10^{-4} \mathrm{pCi} / \mathrm{m}^{3}$ for $\mathrm{U}-238$ and $\mathrm{U}-234$, and $0.45 \times 10^{-4} \mathrm{pCi} / \mathrm{m}^{3}$ for $\mathrm{Th}-230$, with a soil uranium concentration of $1.5 \mathrm{pCi} / \mathrm{g}$. McEachern et a1. (1971) reported an average uranium concentration of about $4 \times 10^{-4} \mathrm{pCi} / \mathrm{m}^{3}$ from measurements at several sites within the State of New York. Breslin and Glauberman (1970) measured an airborne uranium concentration of $1 \mathrm{pCi} / \mathrm{m}^{3}$ in the vicinity of one uranium mill tailings pile. They reported lower concentrations $\left(0.1 \mathrm{pCi} / \mathrm{m}^{3}\right.$ and $\left.0.05 \mathrm{pCi} / \mathrm{m}^{3}\right)$ at two other mill sites. Ra-226 concentrations ranged from 0.04 to $0.2 \mathrm{pCi} / \mathrm{m}^{3}$. The data from these authors seem to indicate that airborne concentrations of radionuclides are reduced about tenfold at a distance of about $1 \mathrm{~km}$ from the site of origin.

The average airborne concentration of $\mathrm{Pb}-210$ seems to range from $1 \times 10^{-3}$ to $3 \times 10^{-2} \mathrm{pCi} / \mathrm{m}^{3}$ (NRCP $\# 451975$ ). Poet et a1. (1972) report concentrations of $\mathrm{Pb}-210$ ranging from $1 \times 10^{-3}$ to $2.1 \times 10^{-2} \mathrm{pCi} / \mathrm{m}^{3}$. A survey by Magno et a1. (1970) of airborne $\mathrm{Pb}-210$ in several states showed concentrations of $2.6 \times 10^{-2} \mathrm{pCi} / \mathrm{m}^{3}$ (Illinois and Utah) and about $1.5 \times 10^{-2} \mathrm{pCi} / \mathrm{m}^{3}$ (California and Massachusetts). The lowest concentration reported $\left(5 \times 10^{-3} \mathrm{pCi} / \mathrm{m}^{3}\right)$ was in the State of Hawaii. 
Our preliminary theoretical calculations using the UDAD Code as a tool for prediction of an optimum monitoring station show a 100-fold reduction in airborne uranium concentration at station 105 (Fig. 2) relative to the concentration at the mill. The UDAD calculations also predicted a $\operatorname{Ra}-226$ concentration of about $5 \times 10^{-5} \mathrm{pCi} / \mathrm{m}^{3}$ at that distance. This concentration is about the same as the reported background concentration for $\mathrm{Ra}-226$. Because of variation in topography and ground canopy conditions, it is difficult to select stations for measurement of the background radionuclide concentrations that are representative of the area around the Anaconda mill, yet sufficiently outside the zone of mill influence. The particulate concentrations at station 105, over $2 \mathrm{~km}$ from the tailings, were assumed to represent estimates of the background concentrations for this study. Additional measurements at distances farther removed from the Anaconda mill are necessary to justify our selection of station 105 as being representative of regional background.

The reported background airborne concentrations of $1.2 \times 10^{-4} \mathrm{pCi}$ $\mathrm{U}-238 / \mathrm{m}^{3}$ (Sedlet et al. 1973) and $4 \times 10^{-4} \mathrm{pCi} \mathrm{U-238} / \mathrm{m}^{3}$ (McEachern et al. $1971)$ are smaller than the average $\left(1.2 \times 10^{-3} \pm 1.3 \times 10^{-4} \mathrm{pCi} \mathrm{U-238/ \textrm {m } ^ { 3 }}\right)$ measured in this study at station 105, considered to be representative of background in the Anaconda mill area. The concentration ( $\mathrm{pCi} / \mathrm{m}^{3}$ ) of uranium measured at station 105 ranged between $4.31 \times 10^{-4} \pm 4.3 \times 10^{-5}$ and $2.52 \times 10^{-3} \pm 2.5 \times 10^{-4}$. This entire range is above the previously reported background concentrations for regions of New York (McEachern 1971) and the Chicago area (Sedlet et a1. 1973). We surmise that this higher concentration may be partially a result of the higher mineralization of soil in this region of New Mexico (Fig. 1) than in the regions east of the Mississippi River.

Similarly, concentrations $\left(\mathrm{pCi} / \mathrm{m}^{3}\right)$ of $\mathrm{Th}-230$, $\mathrm{Ra}-226$, and $\mathrm{Pb}-210$ at station 105 were, respectively, $1.7 \times 10^{-3} \pm 2.2 \times 10^{-4}, 7.5 \times 10^{-4} \pm 1.1 \times 10^{-4}$ and $1.4 \times 10^{-2} \pm 1.4 \times 10^{-3}$. The estimated average value $\mu$ for the concentrations $\left(\mathrm{pCi} / \mathrm{m}^{3}\right)$ at the confidence level of two standard errors of the mean would be $1.3 \times 10^{-3}<\mathrm{Th}-230<2.1 \times 10^{-3}, 5.3 \times 10^{-4}<\mathrm{Ra}-226<9.7 \times 10^{-4}$, and $1.1 \times 10^{-2}<\mathrm{Pb}<1.7 \times 10^{-2}$. Comparison of $\mathrm{Th}-230$ concentration at this station with the value measured by Sedlet et a1. (1973) for the Argonne National Laboratory area $\left(4.5 \times 10^{-5} \mathrm{pCi} / \mathrm{m}^{3}\right)$ suggests at least an order of magnitude higher concentration for the Anaconda area. The estimated $\mathrm{Pb}-210$ concentration at station 105 is within the range of values reported by Poet et a1. (1972) and Magno et a1. (1970).

The current limit of total exposure from inhalation of airborne particulates (maximum permissible concentration, MPC) for the general public at unrestricted areas of uranium milling operations is specified in the U.S. Code of Federal Regulations, 10 CFR Part 20, Appendix B.* of all the radionuclides in the U-238 series, the MPC is lowest for soluble thorium $(\mathrm{Th}-230 \mathrm{~S})--8 \times 10^{-2} \mathrm{pCi} / \mathrm{m}^{3}\left(8 \times 10^{-14} \mathrm{\mu Ci} / \mathrm{mL}\right)$. The highest $\mathrm{MPC}, 8 \mathrm{pCi} / \mathrm{m}^{3}$, is for insoluble lead $(\mathrm{Pb}-210 \mathrm{I})$.

* Code of Federal Regulations, Office of the Federal Register, National Archives and Records Service, General Service Administration, January 1975. At the end of 1980, 40 CFR Part 190, which establishes an exposure 1imit of $25 \mathrm{mrem} / \mathrm{yr}$, will go into effect for uranium mills. 
The average concentration of each radionuclide measured in the vicinity of the Anaconda mill is compared with the appropriate MPC in Table 13. Stations 102 and 104 (Fig. 2) are near the boundary of the mill site, and station 103 is well within the site and in the direction of maximum transport of particulates from the tailings surface. The average particulate concentration at station 103 is 2 to 5 times higher than at other stations for all radionuclides except for U238. Uranium concentration is highest at station 104 and probably is dominated by the releases from the uranium dryer stacks. The ratio of the average particulate concentrations $(\bar{X})$ measured at Anaconda to the appropriate MPC $(\bar{X} / \mathrm{MPC})$ is the largest for Th-230 S at station 104 $\left(1.5 \times 10^{-2}\right)$ and lowest for $\mathrm{Ra}-226 \mathrm{~S}$ at station $102\left(1.1 \times 10^{-3}\right)$.

Since the average particulate concentrations given include all particle sizes, the respirable fraction of the concentrations is less than the total concentration. Therefore, the ratios ( $\bar{\chi} / \mathrm{MPC}$ ) given in Table 13 are conservative, and the ratios for only the respirable fraction of the particulates probably are less than the values given in Table 13. Furthermore, the airborne particulates are a mixture of soluble and insoluble fractions, and again the highest $(\bar{X} / \mathrm{MPC})$ ratio given in the table for each radionuclide is thus conservative. A better estimate of the particulate concentration based on the aerodynamic size distribution will be reported in the future. Based on data in Table 13, the airborne particulate concentrations at the Anaconda boundary were well below the maximum permissible concentrations for inhalation exposure of the general population in unrestricted areas as specified in 10 CFR Part 20. Comparison of the airborne radionuclide concentrations at the Anaconda mill with 40 CFR 190 regulations, which go into effect for uranium mills at the end of 1980 , will be reported in the future. 
Table 13. Comparison of the Average Particulate Concentrations $(\bar{\chi})$ Measured by the Continuous Sampling Method with the Maximum Permissible Concentration (MPC) or Soluble (S) and Insoluble (I) Radionuclides

\begin{tabular}{|c|c|c|c|c|c|c|c|}
\hline \multirow[b]{2}{*}{ Radionuclide } & \multirow[b]{2}{*}{$\begin{array}{c}\mathrm{MPC}^{\mathrm{a}} \\
\left(\mathrm{pCi} / \mathrm{m}^{3}\right)\end{array}$} & \multicolumn{2}{|c|}{ Station 102} & \multicolumn{2}{|c|}{ Station 103} & \multicolumn{2}{|c|}{ Station 104} \\
\hline & & $\begin{array}{c}\bar{x} \\
\left(\mathrm{pCi} / \mathrm{m}^{3}\right)\end{array}$ & $(\bar{x} / \mathrm{MPC})$ & $\begin{array}{c}\bar{x} \\
\left(\mathrm{pCi} / \mathrm{m}^{3}\right)\end{array}$ & $(\bar{x} / \mathrm{MPC})$ & $\begin{array}{c}\bar{x} \\
\left(\mathrm{pCi} / \mathrm{m}^{3}\right)\end{array}$ & $(\bar{x} / M P C)$ \\
\hline & 3 & $2.2 \times 10^{-3}$ & & $1.8 \times 10^{-3}$ & & $8.8 \times 10^{-3}$ & $2.9 \times 10^{-3}$ \\
\hline$U-238 I$ & 5 & & $4.4 \times 10^{-4}$ & & $3.6 \times 10^{-4}$ & & $1.8 \times 10^{-3}$ \\
\hline $\mathrm{Th}-230 \mathrm{~s}$ & $8 \times 10^{-2}$ & $13 \times 10^{-3}$ & $1.6 \times 10^{-2}$ & $55 \times 1 a^{-3}$ & $6.9 \times 10^{-2}$ & $10-3$ & $1.5 \times 10^{-2}$ \\
\hline$T h-230 \mathrm{I}$ & $3 \times 10^{-1}$ & & $4.3 \times 10^{-3}$ & & $1.8 \times 10^{-2}$ & & $4.0 \times 10^{-3}$ \\
\hline $\mathrm{Ra}-226 \mathrm{~S}$ & 3 & $10-3$ & $1.1 \times 10^{-3}$ & $10-3$ & $2.4 \times 10^{-3}$ & $10-3$ & $4.3 \times 10^{-4}$ \\
\hline $\mathrm{Ra}-226 \mathrm{I}$ & 2 & & $1.7 \times 10^{-3}$ & & $3.7 \times 10^{-3}$ & & $6.5 \times 10^{-4}$ \\
\hline $\mathrm{Pb}-210 \mathrm{~S}$ & 4 & & $6.8 \times 10^{-3}$ & & $6.0 \times 10^{-3}$ & & $3.5 \times 10^{-3}$ \\
\hline $\mathrm{Pb}-210 \mathrm{I}$ & 8 & $2.7 \times 10^{-2}$ & $3.4 \times 10^{-3}$ & $2.4 \times 10^{-2}$ & $3.0 \times 10^{-3}$ & $1.4 \times 10^{-2}$ & $1.8 \times 10^{-3}$ \\
\hline
\end{tabular}

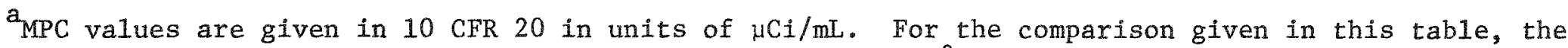
10 CFR $20 \mathrm{MPC}$ values have been converted to units of $\mathrm{pCi} / \mathrm{m}^{3}$. 


\section{REFERENCES}

Breslin, A.J., and H. Glauberman. 1970. "Investigation of Radioactive Dust Dispersed from Uranium Tailings Piles," In: "Environmental Surveillance in the Vicinity of Nuclear Facilities," W.C. Reincing (ed.), p. 249, Charles Thomas, Springfield, IL.

Magno, P.J., P.P. Groulx, and J.C. Apidianakis. 1970. "Lead-210 in Air and Total Diets in the United States During 1966," Health Physics $18: 383$.

McEachern, P., W.G. Myers, and F.A. White. 1971. "Uranium Concentration in Surface Air at Rural and Urban Localities Within New York State," Env. Sci. and Tech. 5:700-703.

Momeni, M.H., W.E. Kisieleski, Y. Yuan, and C.J. Roberts. 1978. "Radiological and Environmental Studies at Uranium Mills: A Comparison of Theoretical and Experimental Data," Paper presented at Seminar on Management, Stabilisation and Environmental Impact of Uranium Mill Tailings, OECD Nuclear Energy Agency, 24-28 July 1978, Albuquerque, NM.

Momeni, M.H., Y. Yuan, and A.J. Zielen. 1979(a). "The Uranium Dispersion and Dosimetry (UDAD) Code," Argonne National Laboratory, NUREG/CR-0553, ANL/ES-72.

Momeni, M.H., W.E. Kisieleski, D.R. Rayno, C.S. Sabau. 1979(b). "Radioisotopic Composition of Yellowcake: An Estimation of Stack Release Rates," Argonne Nationa1 Laboratory, NUREG/CR-1216, ANL/ES-84.

Momeni, M.H., W.E. Kisieleski, S. Tyler, A. Zielen, Y.C. Yuan, and C.J. Roberts. 1979(c). "Radiological Impact of Uranium Tailings and Alternatives for Their Management," Paper presented at the Health Physics Society Twelfth Midyear Topical Symposium on Low Level Radioactive Waste Management, 12-15 February 1979, Williamsburg, VA.

National Council on Radiation Protection and Measurements (NCRP 非5). 1975. "Natural Background Radiation in the United States," Report \#45.

Poet, S.E., H.E. Moore, and E.A. Marte11. 1972. "Lead-210, Bismuth-210 and Polonium-210 in the Atmosphere," J. Geophys. Res. 77:6515.

Sedlet, J., N.W. Golchert, and T.L. Duffy. 1973. "Environmental Monitoring at Argonne National Laboratory - 1972," Argonne National Laboratory, ANL-8007.

U.S. Nuclear Regulatory Commission (NRC). 1979.' "Draft Generic Environmental Impact Statement on Uranium Mil1ing," Project M-25, NUREG-0511. 
Distribution of NUREG/CR-1320 (ANL/ES-89)

Interna1:

J.D. DePue

A.J. Dvorak

D. Grahn

P.F. Gustafson

W.J. Hallett

W.E. Kisieleski (2)
J.H. Kitte1

J.H. Martens

W.E. Massey

M.H. Momeni (15)

G.L. Montet

A.E. Packard
C.J. Roberts

J. Rundo

W.K. Sinclair

A.F. Stehney

A.J. Zielen

ANL Contract File

ANL Libraries (5)

TIS Files (6)

\section{External:}

USNRC, for distribution per RU (343)

DOE-TIC (2)

Manager, Chicago Operations and Regional office, DOE

Chief, Office of Patent Counsel, DOE-CORO

President, Argonne Universities Association

Abyss, J., United Nuclear - Homestake Partners, P.0. Box 3951, Albuquerque, NM 87110

Bever1y, R.G., Union Carbide Corp., P.0. Box 1029, Grand Junction, Co 81501

Breslin, A.J., Health and Safety Laboratory, USDOE, New York, NY 10014

Geiger, E., Eberline Co., Santa Fe, NM 87501

Phillips, C.R., Univ. of Toronto, Dept. of Chemical Engineering, Toronto, Ontario, Canada M55 IA4

Range, D., Exxon Minerals Co., P.O. Box 3020, Casper, WY 82602 